\title{
YARGI KARARLARI IŞIĞINDA IDARİ YARGILAMA USULÜNDE TANIK
}

\author{
(Araştırma Makalesi)
}

DOI: https://doi.org/10.33717/deuhfd.998237

Arş. Gör. Dr. Sezin ÖZTOPRAK*

\section{$\ddot{O} \mathbf{z}$}

İdari yargılama usulünde tanık delilinin iki farkl boyutu bulunmaktadır. Öncelikle, idari yargılama usulünde, Danıștay kararları doğrultusunda, yargllama aşamasında tanık dinlenmemektedir. Bununla birlikte, idari usul sürecinde ya da adli yargl yerlerince dinlenmiş olan tanıkların ifadeleri idari yargı yerlerince delil olarak kullanılmaktadır. Tanık delilinin iki boyutu da adil yargllanma hakkı ve vicdani kanaat ilkesi ile yakından ilişkili olup bu husus Avrupa Insan Haklar Mahkemesi ve Anayasa Mahkemesi kararlarında da vurgulanmaktadir. Bu çalışmada, öncelikle Danıştay kararları doğrultusunda, idari yargılama aşamasında tanık dinlenmemesinin gerekçeleri değerlendirilmiş, ardından dolaylı olarak idari yargılama sürecine etki eden tanık ifadelerine iliş̧kin açıklamalar yapılmıştır. Son olarak adil yargılanma hakkı ve vicdani kanaat ilkesi açısından idari yargılama usulünde tanık dinlenmesinin gerekliliği vurgulanmaya çalışılmiştır.

\section{Anahtar Kelimeler}

Tanı, Adil yargılanma hakkl, Vicdani kanaat ilkesi, Yazılı yargılama usulü, Sözlü yargllama usulü, İdari usul

\section{WITNESS IN ADMINISTRATIVE JUDICIAL PROCEDURE IN THE LIGHT OF JUDICIAL DECISIONS}

\section{(Research Article)}

\begin{abstract}
There are two different legal dimensions of the evidence of witness in administrative judicial procedure. Primarily, in administrative judicial

Selçuk Üniversitesi Hukuk Fakültesi, İdare Hukuku Anabilim Dalı, Konya (avsezin@ hotmail.com), ORCID: 0000-0002-9460-9583 (Geliş Tarihi: 04.04.2021-Kabul Tarihi: 09.07.2021)
\end{abstract}


procedure, in the direction of the decisions of Council of State, the witness is not heard in jurisdiction period. However, the statements of the witnesses who were heard in the period of administrative procedure or by ordinary justice places are used as evidences by administrative justice places. The two legal dimensions of the evidence of witness are hand in and glove with the right to fair trial and the principle of personal conviction and this matter is also emphasized in the decisions of European Court of Human Rights and Constitutional Court. In this study, firstly judicial opinions why witness has not been heard in administrative judicial procedure has been evaluated in the direction of the decisions of Council of State, after the witness statements, which have impact to admininistrative jurisdiction period edgeways, has been explained. Finally, the necessity of hearing witness in administrative jurisdiction procedure has been tried to emphasise in terms of right to fair trial and the principle of personal conviction.

\section{Keywords}

Witness, Right to fair trial, The principle of personal conviction, Written proceeding, Oral proceeding, Administrative procedure. 


\section{GİRIŞ}

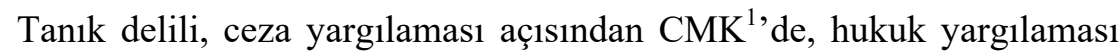
açısından $\mathrm{HMK}^{2}$, de ayrıca ve açıkça düzenlenmiş olup, ceza ve hukuk yargılamaları sırasında sıklıkla bu delile başvurulmaktadır. İdari yargılama usulünde ise, IYYUK ${ }^{3}$ 'ta tanık delili de dâhil olmak üzere hiçbir delil ayrıca düzenlenmemiş, sadece bilirkişi ve keşif delilleri ile ilgili olarak IYYUK-md. 31 'de HMK'ye atıf yapılmıştır. Buna ek olarak, IYUK-md.31'de, kanunda hüküm bulunmayan ve HMK'ye atıf yapılmayan hallerde vergi uyuşmazlıklarının çözümünde $\mathrm{VUK}^{4}$, un uygulanacağı belirtilmiş olsa da; VUK-md. 3 'te düzenlenmiş olan tanık ifadesi Danıştay tarafından vergilendirme süreci açısından kabul edilmiş, VUK-mükerrer md. 378'de duruşma sırasında dinleneceği belirtilen kişiler ise madde hükmünde sayılan kişilerle sınırlandırılmıştır.

Böylelikle, hukuk ve ceza yargılamalarının aksine, idari yargılama aşamasında sözlü olarak tanık dinlenememektedir. Bununla birlikte, idare hukukunda disiplin cezaları başta olmak üzere çok sayıda idari işlemin hazırlık aşamasında tanık ifadeleri önemli bir yer teşkil etmekte ve Danıştay yargılama sırasında bu ifadeleri delil olarak kullanabilmektedir. Benzer şekilde, adli yargı yerlerince dinlenmiş olan tanıkların ifadeleri bazı idari uyuşmazlıkların çözümünde delil olarak kabul edilmektedir.

İdari yargılama usulünde tanık dinlenmesinin önemi ile ilgili olarak, uzun zamandır doktrinde çok sayıda çalışma yapılmış olmasına rağmen, ne yazık ki bu hususta bir ilerleme kaydedilmemiştir. Bununla birlikte, adil yargılanma hakkı ve vicdani kanaat ilkesi ile yakın ilişki içinde bulunan tanık dinletme hakkının önemi son yıllarda bireysel başvuru sonucu verilen Anayasa Mahkemesi kararlarına yansımıştır. Bazı noktalarda tekrara düşme kaygısı taşıyan bu çalışmanın yapılmasının temel sebepleri, tanık delilinin idari yargilama usulündeki iki boyutunu ortaya koyabilmek ve idari yarg1lama aşamasında tanık dinlenmesinin önemini vurgulayabilmektir.

$\mathrm{Bu}$ amaçla yapılmış olan çalışmada, Danıştay'ın tanık delili ile ilgili kararları incelenmiş ve çalışmanın ilk iki bölümü bu çerçevede oluşturulmuştur. Buna göre, çalışmanın ilk bölümünde, Danıştay'ın idari yargılama aşamasında tanık dinlememesine ilişkin gerekçeleri değerlendirilecek; ikinci

5271 Sayılı Ceza Muhakemesi Kanunu; RGT. 17.12.2004, RGS. 25673.

6100 Sayılı Hukuk Muhakemeleri Kanunu; RGT. 04.02.2011, RGS. 27836.

2577 Sayılı İdari Yargılama Usulü Kanunu; RGT. 20.01.1982, RGS. 17580.

213 Sayılı Vergi Usul Kanunu; RGT. 10.01.1961, RGS. 10703. 
bölümde ise Danıştay'ın, idari usul sürecinde ve adli yargı aşamasında dinlenmiş olan tanık ifadelerini delil olarak kullandığ 1 çok sayıda karara ilişkin değerlendirmeler yapılacaktır. Çalışmanın üçüncü bölümünde ise, Avrupa İnsan Hakları Mahkemesi ve Anayasa Mahkemesi'nin kararları doğrultusunda, idari yargılama usulünde tanık delilinin adil yargılanma hakkı ve vicdani kanaat ilkesi ile ilişkisi açıklanmaya çalışılacaktır.

$\mathrm{Bu}$ şekilde sonlandırılacak olan çalışmada, idari yargılama usulünde tanık dinlenmesine yönelik mevzuat ya da içtihat değişikliği gerekliliğinin, daha önceden çok sayıda yazar tarafından vurgulanmış olduğu gibi, bir kez daha altının çizilmesi ve Yarg1 Reformu Stratejisi Eylem Planı'nda belirtilmiş olduğu gibi, tanık deliline ilişkin düzenlemelerin yapılması umulmaktadir.

\section{IDARI YARGILAMA AŞAMASINDA TANIK DİNLENMEMESI}

\section{A. İdari Yargılama Aşamasında Tanık Dinlenmemesinin Gerekçeleri}

IYYUK'ta tanık deliline ilişkin herhangi bir düzenleme yer almamakta olup, idari yargılama aşamasında sözlü olarak tanık dinlenemeyeceğine ilişkin kabul, Danıştay içtihatları ile söz konusu olmuştur. Danıştay'ın bu husustaki içtihadına temel teşkil eden eski tarihli iki kararı, vergi uyuşmazlıklarına ilişkindir. Danıştay 3. Dairesi'nin söz konusu kararlarında, idari yargılama usulünde yazılı yargılama usulünün geçerli olduğu ve IYYUKmd.31'de tanık delili ile ilgili olarak HMK'ye atıf yapılmamış olduğu için, tanık delilinin idari yargılama usulünde kabul edilemeyeceği belirtilmiştir. Danıştay aynı gerekçelere dayanarak duruşma sırasında tanık dinlenmesini kabul etmediği gibi ${ }^{5}$; keşiften sonra davacı tarafından getirilen ve ifadeleri tutanağa geçirilen tanık ifadesini de kabul etmemiştir ${ }^{6}$. Bu durumda, söz konusu tanıklar keşif sırasında dinlenmiş olsaydı Danıştay'ın tanık ifadesini kabul edeceğini söylemek mümkün ${ }^{7}$ olabilse de bireysel başvuruya konu olmuş bir idare mahkemesi kararında açıkça "...idari yargılama usulünde keşif sırasında ya da yargılamanın herhangi bir aşamasında tanık dinlenil-

D3D, E.1986/1201, K.1986/2706, KT.24.12.1986; www.hukukturk.com; e.t.03.03.2021. D3D, E.1989/3460, K.1990/3569, KT.25.12.1990; www.hukukturk.com; e.t.03.03.2021. Bununla birlikte, söz konusu karar, doktrinde, Danıştay'ın keşif sırasında tanık beyanını kabul etmediği şeklinde yorumlanmıştır. Bkz. Akyılmaz, Bahtiyar/Sezginer, Murat/ Kaya, Cemil: Türk İdari Yargılama Hukuku, 2. Baskı, Savaş Yayınevi, Ankara, 2019, s. 638. 
mesi usulünün olmadiğg ...", belirtilmiş ve Danıştay’ın yargılama sırasında yapılan keşifte tanık dinlenebileceğine ilişkin bir kararına bu çalışma kapsamında ulaşılamamış olduğundan ${ }^{9}$, bu kez idari yargılama aşamasında keşif sırasında da tanık dinlenmeyeceğinin kabul edilmiş olduğunu söylemek mümkün hale gelmektedir.

Oysa keşifle ilgili olarak IYUK-md. 31'in HMK'ye yaptığı atıf gereği keşif sırasında tanık dinlenmesi mümkündür ${ }^{10}$. Benzer şekilde, VUKmd. $3^{11}$ te, tanık ifadesi delil olarak kabul edilmekte ${ }^{12}$ olduğundan, vergi uyuşmazlıklarında da tanık dinlenmesi kabul edilebilmelidir. Bununla birlikte, Danıştay kararlarında "vergiyi doğuran olayla ilişkisi doğal ve açık bulunan tanık ifadesi" nin gerçek mahiyetin ortaya çıkarılmasında başvurulacak bir delil olduğu vurgulanmakta ${ }^{13}$ ise de Danıştay bu hususu sadece

AYM, BN. 2013/6615, KT.20.04.2016; www.hukukturk.com; e.t. 25.03.2021.

9 Danıştay'ın idari usul sürecinde yapılan keşif sırasında dinlenen tanıklarla ilgili değerlendirmelere yer vermiş olduğu kararları ise bulunmaktadır. Örnek için bkz. "Dava, ... $i l i$, ... ilçesine bağlı .... köyüne ait bulunan yaylaya davacılar tarafindan sahip çıkılmak ve yaylayı kiralayan yaylacıları taciz etmek suretiyle tecavüzde bulunduklarından bahisle yapılan tecavüzün men'ine dair... Kaymakamlığı'nın kararının iptali istemiyle açılmıştır...IIdare Mahkemesince, uyuşmazlık konusu yere davacıların tecavüzde bulunduğunun mahallinde yapılan keşif ve düzenlenen tanık beyanlarıyla sabit bulunduğundan, 3091 sayıl Yasaya göre verilen kararda mevzuata aykırılık görülmediği gerekçesiyle davanın reddine karar verilmiştir...Bu durumda, adliye mahkemesinde açılmış bulunan elatmanın önlenmesi davası Kaymakamlı̆̆ın, 3091 sayıl Yasa ve uygulama yönetmeliği hükümleri uyarınca soruşturma yapmasına ve karar vermesine engel oluşturduğundan, bu durum dikkate alınmaksızın davanın reddi yolunda verilen idare mahkemesi kararında hukuki isabet bulunmamaktadir...”; D10D, E.1999/4852, K.2001/3433, KT.08.10.2001; www.hukukturk.com; e.t.03.03.2021.

10 HMK-md. 290/2: "Mahkeme keşif sırasında tanık ve bilirkişi dinleyebilir...". Bu hususta ayrıca bkz. Akyılmaz/Sezginer/Kaya, s. 638; Çınarlı, Serkan/Azak, Kerim: "Danıştay Kararları Işı̆̆ında İdari Yargıda Disiplin Cezalarının İptali Davalarında Tanık Delili Sorunu”, Selçuk Üniversitesi Hukuk Fakültesi Dergisi, Cilt 29, Sayı 1, 2021, s. 524; Çebi Buğdaycı, Melike Özge: "İdari Yargılama Usulünde Keşif Delili”, Selçuk Üniversitesi Hukuk Fakültesi Dergisi, Cilt 29, Sayı 1, 2021, s. 33.

11 VUK-md. 3:“...Vergiyi doğuran olay ve bu olaya ilişkin muamelelerin gerçek mahiyeti yemin hariç her türlü delille ispatlanabilir. Şu kadar ki, vergiyi doğuran olayla ilgisi tabii ve açık bulunmayan şahit ifadesi ispatlama vasıtası olarak kullanılamaz..."

12 Uzun, Mine: "Bir Adil Yargılanma Hakkı Olarak Tanığ Hakkının Türk Vergi Yargılamasındaki Yeri”, Ankara Üniversitesi Hukuk Fakültesi Dergisi, Cilt 63, Sayı 1, 2014, s. 230; Ceylan, Mahmut: "İdari Yargıda Delil Serbestisi ve Sinırları", Karadeniz Teknik Üniversitesi Sosyal Bilimler Enstitüsü Sosyal Bilimler Dergisi, Y11 8, Say1 16, Aralık 2018, s. 330.

13 D9D, E.2017/1234, K.2020/696, KT.12.02.2020; D9D, E.2018/61, K.2020/1084, KT.24.02.2020; www.hukukturk.com; e.t.03.03.2021. 
vergilendirme sürecine ilişkin görmekte, yargılama aşamasında ayrıca tanık ifadesi alınmasını ise, idari yargıda tanık dinlenemeyeceğine ilişkin kararlarındaki gerekçeleri kullanarak bozma sebebi olarak kabul etmektedir ${ }^{14}$. Danıştay eski tarihli bir kararında, vergi hukukunda bazen tanık ifadelerinden yararlanmanın zorunlu olduğuna ve bu beyanların maddi delil olarak kabul edilmesi gerektiğine karar vermiş olsa da bu kararda mahkeme huzurunda alınan bir tanık ifadesi değil, uyuşmazlığa konu komisyon kararının alınması sırasındaki tanık ifadesinden bahsedilmektedir ${ }^{15}$. Sonuç olarak, Danıştay VUK-md. 3'te yer alan tanık ifadesini vergilendirme sürecine ilişkin olarak kabul etmektedir. Böylece, vergilendirme sürecinde alınan tanık ifadeleri de yazılı delil haline dönüşmüş olmaktadır. VUK'ta tanıkla ilgili diğer hüküm ise, duruşma sırasında belli kişilerin de dinlenebilmesini hüküm altına alan mükerrer 378. maddedir ${ }^{16}$. Bu madde ile, vergi davalarında sınırlı da olsa, tanık dinlenebilmesi kanunen hüküm altına alınmıştır. Doktrinde, vergi davalarında bu şekilde dinlenebilecek olan kişiler, "kısıtıl şahit" olarak adlandırılmıştır ${ }^{17}$.

Böylelikle, idari yargılama usulünde VUK- mükerrer md. 378 doğrultusunda sadece bu madde hükmünde belirtilen kişiler tanık olarak dinlenebilmekte, VUK- md. 3'te açık düzenleme bulunmasına rağmen, vergi uyuşmazlıklarında bu madde doğrultusunda tanık dinlenmesini Danıştay kabul etmemektedir. Aslında, idari yargılama usulünde, vergi uyuşmazlıkları dışındaki uyuşmazlıkları da kapsayacak şekilde tanık dinlenmemesinin gerekçeleri, vergi uyuşmazlıklarına ilişkin söz konusu içtihattan temellenmiştir.

Danıştay, yazılı yargılama usulünün benimsenmiş olması ve HMK'ye atıf yapılmamış olmasına ilişkin gerekçeleri, vergi uyuşmazlıkları dışında az sayıdaki başka idari uyuşmazlıkta da kullanmış ${ }^{18}$, bazılarında ise gerekçeye yer vermeksizin tanık dinlenmesi talebini kabul etmemiştir. Örneğin, idareye karşı açmış olduğu tam yargı davasında davacı ilk derece aşamasında tanık dinletmek istemiş, ilk derece mahkemesince bu talebi reddedilmiş ve dava konusu zarara kişisel kusurunun sebep olduğu gerekçesi ile davanın reddine

14 Uzun, s. 232.

15 D4D, E.1978/1623, K.1978/3550, KT.23.11.1978; www.hukukturk.com; e.t.03.03.2021.

16 VUK-Mükerrer md. 378: "Danıştay ve vergi mahkemelerinde yapılacak duruşmalarda, iddia ve savunmanın gerekli kıldığ hallerde, mahkeme vergi davasına konu olan tarhiyatın dayană̆ incelemeyi yapmış bulunan inceleme elemanları ile, mükellefin duruşmada hazır bulundurduğu mali müşaviri veya muhasebecisini de dinler."

17 Hondu, Selçuk: "İdari Yargılama Usulünde Deliller ve "Şahit"”, Özay İl Han, Günışığında Yönetim II Yargısal Korunma, Filiz Kitabevi, İstanbul, 2004, s. 264.

18 D8D, E.2003/3369, K.2004/917, KT.25.02.2004; www.hukukturk.com; e.t.03.03.2021. 
karar verilmiştir. Davacı, bu kez Danıştay’a yapmış olduğu temyiz başvurusunda, tanık dinletme talebinin reddedildiğini ve ilk derece mahkemesi kararının salt idarenin görevlilerinin beyanlarına dayanılarak verilmiş olduğunu belirtmiş olsa da Danıştay ilk derece mahkemesi kararını onamıştır ${ }^{19}$.

Doktrinde, idari yargılama hukukunda benimsenmiş olan tanık dinlenmemesine ilişkin kabulün, yazılılık ilkesinin ispat sürecindeki yansıması olduğ $^{20}$, böylece hem idari yargılama usulünde yazılı yargılama usulünün benimsenmiş olması hem de IYYUK-md. 31'de tanık delili ile ilgili olarak HMK'ye atıf yapılmamış olması sebepleriyle mevzuat hükümleri çerçevesinde idari davalarda tanık dinlenmesinin mümkün olmadığ ${ }_{1}^{21}$, belirtilmektedir. Bununla birlikte, idare ve vergi mahkemelerinde görülen bazı uyuşmazlıkların "sağlıklı ve adaletli" şekilde çözümlenebilmesi için tanık deliline ihtiyaç duyulduğu da kabul edilmektedirr ${ }^{23}$. Bu yöndeki görüş doğrultusunda, idari yargılama usulünde mahkeme huzurunda tanık dinlenebilmesi ancak IYYUK'a bu konuda bir düzenleme eklenmesi ile mümkün olabilecektir. Bu husustaki diğer görüş ise, IYYUK'un mevcut durumuyla dahi idari yargılama aşamasında tanık dinlenebileceğ ${ }^{24}$ ve bu hususta içtihat değişikliğine gidilmesinin yerinde olacağ ${ }_{1}^{25}$ yönündedir.

Danıştay'ın tanık delili ile ilgili içtihadı uzun zamandır doktrinde eleştirilmiş olmakla birlikte, bu doğrultuda ne mevzuat değişikliği yapılmış ne de Danıştay içtihadında değişiklik olmuştur. Aşağıdaki başlıklarda, Danıştay ve doktrinde bazı yazarlar tarafından kabul edilen gerekçelerin idari yargı-

19 D10D, E.1992/3677, K.1993/4203, KT.02.11.1993; www.hukukturk.com; e.t.03.03.2021

20 Yasin, Melikşah: İdari Yargılama Usulünde İspat, On İki Levha Yayıncıllk, İstanbul, 2015, s. 36.

21 Hondu, s. 259; Işıklar, Celal: "İdarî Yargıda Duruşma”, Türkiye Adalet Akademisi Dergisi, Cilt 2, Y1l 2, Sayı 4, 2011, s. 81. Hukuk yargılamasına ilişkin kanunların idari yargılama usulünde uygulanabilmesi için mutlaka açık bir kanun hükmü gerektiği hususunda ayrıca bkz. Onar, Siddık Sami: İdare Hukukunun Umumî Esasları, Cilt III, 3. Bask1, İsmail Akgün Matbaas1, İstanbul, 1966, s. 1939.

22 Uyuşmazlık konusu ile ilgili olarak mahkemeden tanık dinlenilmesi talep edilmiş olan bazı dava örnekleri için bkz.; Hondu, s. 260-261.

23 Hondu, s. 259.

24 Bkz. Yılmaz, Dilşat: “ "Usul Ekonomisi İlkesi” Çerçevesinde Türk İdari Yargılama Usulünde Sözlülük İlkesine İlişkin Bazı Değerlendirmeler”, Ankara Hacı Bayram Veli Üniversitesi Hukuk Fakültesi Dergisi, Cilt XXIII, Sayı 2, Y11 2019, s. 302-313'deki açıklamalar.

25 Örneğin bkz. Ocak, Memduh: "İdari Yargıda Duruşmanın Adil Yargılanma Hakkı Açısından İncelenmesi”, Türkiye Barolar Birliği Dergisi, Sayı 145, 2019, s. 363. 
lama usulünde tanık dinlenmesine engel teşkil edip etmeyeceği belirlenmeye çalışılacaktır.

\section{B. Yazılı Yargılama Usulünün Tanık Dinlenmesine Engel Teşkil Edip Etmemesi}

İdari yargılama aşamasında tanık dinlenmemesinin gerekçesi olarak kabul edilen yazılı yargılama usulü, idari yargılama usulünde eskiden beri uygulanan bir usul olup, IYYUK-md.1/2'de yer alan kural ile yazılı yargılama usulü idari yargılama usulü açısından kanuni dayanak kazanmıştır ${ }^{26}$. Bundan önce, 521 say1lı Kanun ${ }^{27}$-md. 78 'de yer alan ve idari yargilama usulünde incelemenin evrak üzerinden yapılacağına ilişkin hükmün de yazılı yarg1lama usulünün benimsenmiş olduğuna ilişkin bir hüküm olduğu doktrinde belirtilmiştir $^{28}$. Doktrinde, ayrıca idari yargılama usulünde yazılılık ilkesinin kabul edilmiş olmasının sebebini, Danıştay'ın ilk derece mahkemesi ve yüksek mahkeme olarak görev yaptığı dönemlerde eğer sözlülük ilkesi de kabul edilmiş olsa idi, iş yükünün daha da artacağı ve yargılama sürecinin daha da uzayacağına ilişkin kaygıların oluşturduğu ve fakat idare mahkemelerinin kurulması ile birlikte Danıştay'ın iş yükünün azalmış olduğu ve yaz1l11ı ilkesinin "yeni baştan gözden geçirilmesi” gerektiği ${ }^{29}$, belirtilmiştir. Yazılı1ık ilkesinin yeniden ele alınması gerekliliğine ilişkin bu görüşün hakl1lığı, günümüzde Bölge İdare Mahkemeleri’nin faaliyete geçmiş olması ve Danıştay'ın artık büyük ölçüde içtihat mahkemesi haline dönüşmüş olması gerçeği göz önüne alındığında, daha da artarak idare mahkemeleri, vergi mahkemeleri, bölge idare mahkemeleri ve ilk derece mahkemesi olarak Danıştay'da görülecek uyuşmazlıklarda tanık dinlenmemesinin pratik bir faydası kalmadığı görülebilmektedir.

Bununla birlikte, Danıştay'ın içtihadının günümüzde de değişmemesinin sebebinin IYUK'ta tanık dinlenmesi lehine bir mevzuat değişikliği yapılmamış olması olduğu söylenebilir. Zira, Danıştay'ın günümüzde geçerliğini koruyan içtihadında idari yargılama usulünde tanık delilini kabul etmemesinin temel gerekçesini, IYYUK-md.1/2'de açıkça belirtildiği üzere yazılı yargılama usulünün benimsenmiş olması ve sözlü yargılama usulünün bir örneği olan duruşmaya ilişkin IYYUK-md.17 ve md. 18 'de duruşmada sadece

\footnotetext{
26 Hondu, s. 254-255.

27 Danıştay Kanunu (RGT. 31.12.1964, RGS. 11896)

28 Çağlayan, Ramazan: “İdari Yargılama Usulünde Tanık Delilini Yeri”, Selçuk Üniversitesi Hukuk Fakültesi Dergisi, Cilt 11, Sayı 3-4, Y11 2003, s. 198.

29 Hondu, s. 255.
} 
tarafların dinleneceğinin hüküm altına alınmış olması oluşturmaktadır ${ }^{30}$. Bununla birlikte, yukarıda da belirtilmiş olduğu gibi, keşifle ilgili HMK'ye atıf yapılmış ve HMK'de keşif sırasında tanık dinlenebileceği açıkça belirtilmiş olduğundan, idari yargılama usulünde sözlü yargılama usulünün uygulanabileceği tek durum duruşma olmayıp, keşif sırasında tanık dinlenmesi de aynı kapsamda değerlendirilmelidir. Kaldı ki, kanunen yazılı yargılama usulünün benimsenmiş olması, tek başına tanık dinlenmesine engel teşkil etmemektedir. Zira, sözlü yargılama usulü ile yazılı yargılama usulü arasındaki fark; davacının ve davalının iddia ve savunmalarını mahkemeye sunuş şekillerinden ibaret olup; sözlü yargılama usulünde taraflar iddialarını sözlü olarak mahkemeye sunmaktayken, yazılı yargılama usulünde dilekçelerle sunmakta, yine sözlü yargılama usulü duruşmalarla devam etmekte iken, yazılı yargılama usulünde duruşma bulunmamaktadır ${ }^{31}$. Bu doğrultuda, hukuk yargilamasinda da genel yargılama usulü-HMK-md.316/1-g ve 322/1'in yorumuyla-yazılı yargılama usulüdür ve sözlü yargılama aşaması, yazılı yargılama usulünün aşamalarından birini oluşturmaktadır ${ }^{32}$. Ceza yargılamasında ise, soruşturma aşamasında yazilılık, kovuşturma aşamasında sözlülük ilkesi benimsenmiştir ${ }^{33}$. Bununla birlikte, her iki yargılama usulünde de tanık, uyuşmazlık konusu olayı aydınlatmak için başvurulan deliller arasında kabul edilmekte ve sıklıkla bu delile başvurulmaktadır. İdari yargılama usulünde, IYYUK-md. 17 ila md. 19 arasında bir sözlü yargılama yöntemi olan duruşmaya yer verilmiş, böylece karma bir sistem benimsenmiş ${ }^{34}$ olup, doktrinde sözlülük usulünün gerçek anlamda işlevsel olabilmesinin yolunun, duruşma sırasında tanık dinlenmesinden geçtiğ $\mathrm{i}^{35}$, haklılıkla belirtilmektedir.

Gerçekten, yargılama sırasında usul işlemleri, yazılılık ya da sözlülük şekillerinden biri benimsenerek yapılabilecek olsa da günümüzde bunlardan sadece biri tercih edilmemekte, yargılamanın bazı aşamalarında yazılılık, bazı aşamalarında ise sözlülük usulü benimsenmektedir ${ }^{36}$. Yazılılık ilkesi,

30 D3D, E.1986/1201, K.1986/2706, KT.24.12.1986; D3D, E.1989/3460, K.1990/3569, KT. 25.12.1990; www.hukukturk.com; e.t.03.03.2021.

31 Onar, s. 1935-1936.

32 Bu hususta bkz. Kuru, Baki: Medenî Usul Hukuku, Legal Yayıncılık A.Ş., İstanbul, 2015, s. 151-152; Türkoğlu Üstün, Kâmile: İdari Yargılama Usulüne Hâkim Olan İlkeler, Seçkin Yayıncılık, Ankara, 2019, s. 332-334.

33 Türkoğlu Üstün, s. 334.

34 Onar, s. 1937; Kaplan, Gürsel: "İdari Yargılama Hukukunda Sözlülük Usulü ve Tanık Dinlenebilmesi Hakkında Kısa Bir Değerlendirme”, İstanbul Kültür Üniversitesi Hukuk Fakültesi Dergisi, Cilt 13, Sayı 1, Y11 13, s. 36.

35 Kaplan, s. 38.

36 Türkoğlu Üstün, s. 326. 
sözlülük ilkesine nazaran her ne kadar mahkemenin dava malzemesini tespit etmesi ve koruması ile davanın daha kısa sürede sonuçlanması ihtimali açısından daha avantajlı olsa da maddi olayın tam olarak ispatlanabilmesi açısindan dezavantajlı olmaktadır ${ }^{37}$.

Bu sebeplerle ve tanık delilini açıkça yasaklayan bir hüküm bulunmamas1 sebebiyle, idari yargılama usulünde kural olarak yazılı yargılama usulünün benimsenmiş olmasının, tek başına tanık dinlenmesine engel teşkil ettiğini söylemek mümkün gözükmemektedir ${ }^{38}$.

\section{HMK'ye Atıf Yapılmamış Olmasının Yargılama Sırasında Tanık Dinlenmesine Engel Teşkil Edip Etmediği}

Danıştay'ın, idari yargılama usulünde tanık dinlenmesini kabul etmemesine ilişkin diğer gerekçesi, IYYUK-md. 31'de tanık delili ile ilgili olarak HMK'ye atıf yapılmamış olmasıdır.

\section{Yargılama Usullerinin Kanuniliği İlkesi Karşısında}

Danıştay'ın idari yargılama usulünü düzenleyen kanunlarda hukuk usulünü düzenleyen kanunlara atıf yapılmadığı durumlara ilişkin kararlarının, öncelikle yargılama usullerinin kanuniliği ilkesi karşısındaki durumuna bakilmalıdır.

Bilindiği gibi, eski Danıştay Kanunları'nda da tanık delili ile ilgili olarak HUMK ${ }^{39}$, a atıf yapılmamıştır ${ }^{40}$ ve 1924 Anayasası'nda mahkemelerin yargılama usullerinin kanunla düzenleneceği açıkça belirtilmiş olmasa da 1961 ve 1982 Anayasalarında, bu hususla ilgili olarak açıkça düzenleme bulunmaktadır ${ }^{41}$. Bununla birlikte, 1924 Anayasası döneminde Danıştay, eski tarihli bir karar ${ }^{42}$ ile Danıştay Kanunu'nda boşluk olan durumlarda HUMK hükümlerinin uygulanabileceğini kabul etmişken, daha sonra almış olduğu

37 Türkoğlu Üstün, s. 327-328.

38 Kaplan, s. 39-40; Türkoğlu Üstün, s. 345.

391086 Sayılı Hukuk Usulü Muhakemeleri Kanunu, RGT. 2, 3, 4.07.1927, RGS. 622, 623, 624.

40 Bkz. 3546 Sayılı Devlet Şûrası Kanunu (RGT. 30.12.1938, RGS.4098)- md. 44; 521 Sayılı Danıştay Kanunu - md. 88.

41 Bkz. 1924 AY- md. 53: "Mahkemelerin teşkilâtt, vazife ve salâhiyetleri kanunla muayyendir."; 1961 AY-md. 136: "Mahkemelerin kuruluşu, görev ve yetkileri, işleyişi ve yargılama usûlleri kanunla düzenlenir.”; 1982-AY-md. 142/1: "Mahkemelerin kuruluşu, görev ve yetkileri, işleyişi ve yargılama usulleri kanunla düzenlenir."

42 “...idari kazada hâkimin adli esaslardan ilham alması umumen kabul edilmiş hukuk kaidelerindendir...”; DUH, E. 1937/238, Danıştay Kararlar Dergisi, Sayı 1, s.60. 
içtihadı birleştirme kararı ile ise sadece atıfta bulunulmuş olan hallerde HUMK hükümlerinin uygulanabileceğine karar vermiştir ${ }^{43}$. Danıştay, yargılama usullerinin kanunla düzenlenmesi gerekliliğini açıkça öngören 1961 Anayasası döneminde de bu içtihat doğrultusunda başka kararlar vermiştir ${ }^{44}$. Danıştay'ın, henüz yargılama usullerinin kanunla düzenlenmesi gerekliliğini açıça öngörmemiş olan 1924 Anayasası döneminde oluşturulmuş olan bu içtihadı, 1961 ve 1982 Anayasaları'nın ilgili maddeleri dikkate alınarak değerlendirildiğinde; IYYUK-md. 31'de tanık delili ile ilgili olarak HMK'ye atıf yapılmamış olmasının, idari yargılama aşamasında tanık dinlenememesi için haklı bir gerekçe oluşturduğu ilk bakışta düşünülebilir.

Bununla birlikte, Danıştay'ın idari yargıya ilişkin kanunlarda düzenleme olmadığı ya da atıf yapılmadığı halde hukuk yargılamasına ilişkin usul hükümlerini uyguladığı uyuşmazlıklar göz önüne alındığında; bu gerekçelerin haklı bir sebebi kalmamaktadır. Zira, idari yargılama usulünde tanık dinlenmesi ile ilgili olarak kanunda boşluk bulunmaktadır ve fakat kanunda boşluk bulunan hallerde söz konusu boşluğun içtihatla doldurulup doldurulamayacağı yönündeki Danıştay kararlarının tümü aynı yönde değildir. Danıştay 1961 Anayasası ve 1982 Anayasası döneminde, kanunda hukuk yargılamasını düzenleyen kanunlara açık bir atıf bulunmayan durumlarda söz konusu kanun hükümlerini uygulamıştır. Örneğin, 1961 Anayasası döneminde 521 sayılı Kanun'da atıf yapılmamış olmasına rağmen, dava açma süresinin hesabında, davaların ayrılması ve birleştirilmesinde, derdestlik durumunda hukuk yargılamasına ilişkin kanun hükümlerinden yararlanılmış$\operatorname{tır}^{45}$. Günümüzde de örneğin, derdestlik hususunda bir düzenleme bulunmamakta ve derdestlik ile ilgili olarak Danıştay çok sayıdaki kararında, HMK hükümlerinden yararlanmaya devam etmektedirr ${ }^{46}$. Danıştay bu tutumunu,

43 Devlet Şûrası Dava Daireleri Umumi Heyeti, E. 1952/154, K. 1954/33, KT.05.02.1954; Danıştay Kararlar Dergisi, Sayı 64-65, s. 63.

44 Örneğin bkz. “...Danıştay yasasının 88 inci maddesi hangi hallerde hukuk usulü muhakemeleri kanununun uygulanabileceğini açıkça belirtmiş olup bu müesseseler dışında uygulama yapılamayacağı açıktır...”; D12D, E. 1977/2349, K. 1977/2097, KT. 19.10.1977, Danıştay Dergisi, Sayı 30-31, s. 497. Bu hususta başka bazı karar örnekleri için bkz. Yavuzdoğan, Seçkin: İdari Yargılama Usulü Kanunu'nun 31. Maddesi Çerçevesinde Medeni Yargılama Hukuku-İdari Yargılama Hukuku İlişkisi, Yayımlanmamış Doktora Tezi, İstanbul, 2007, s. 19, dipnot 41.

45 Bu hususta ayrıntılı bilgi için bkz. Eroğlu, Yaşar: "Danıştay Kanunuyla Hukuk Usulü Muhakemeleri Kanunu'na Atıf Yapılmayan Hallerde Hukuk Usulü Muhakemeleri Kanunu'nun Danıştayda Uygulanışı”, Danıştay Dergisi, Sayı 8, Y11 3, 1973, s. 28-31.

46 D10D, E.2011/4625, K.2015/754, KT.25.02.11.2015. Aynı yönde karar için bkz. D14D, E.2016/1259, K.2019/1588, KT.05.03.2019; D8D, E.2016/11196, K.2020/1562, KT. 05. 03. 2020; www.hukukturk.com; e.t.18.03.2021. 
IYUK'ta düzenlenmemiş ve HMK'ya atıf yapılmamış olmasına rağmen kesin hüküm ${ }^{47}$ ve bekletici mesele ${ }^{48}$ ile ilgili olarak da sürdürmektedir. Oysa, derdestlik $^{49}$, kesin hüküm ${ }^{50}$ ve bekletici mesele ${ }^{51}$ de birer yargılama usulü kuralıdır ve İYUK-md. 31'de HMK'ye atıf yapılmamasına rağmen mahkemece bu kurallara başvurulmaktadır. Buna ek olarak Danıştay, yakın tarihli bazı kararlarında 4721 sayı1lı Kanun ${ }^{52}$ un başlangıç hükümlerinden yararlanabileceğini kabul etmekte ${ }^{53}$, bazı uyuşmazlıklarda ise maddi hukukla ilgili olarak 4721 sayılı Kanun'da düzenlenmiş olan hâkimin hukuk yaratma yetkisinden yararlanmaktadır ${ }^{54}$.

Görüldüğü gibi, Danıştay'ın kanunda boşluk bulunması durumundaki yaklaşımı, bütün yargılama usulü kuralları için aynı yönde olmamaktadır. $\mathrm{Bu}$ sebeple, idari yargılama usulünde tanık dinlenmemesine gerekçe olarak kabul edilen IYUK-md. 31'de HMK'ye atıf yapılmamış olması durumu da aslında haklı bir gerekçe olmaktan uzaktır.

Anayasa Mahkemesi'nin de bu husustaki kararları aynı yönde değildir. Örneğin, anayasa yargısını düzenleyen usul kanununda yer almamasına rağmen yürürlüğün durdurulması kurumunu uygulayan Anayasa Mahkemesi, kanunlarda açık hüküm bulunmayan durumlarda hâkimin hukuk yaratabileceğini, bunun çağdaş hukuk sistemlerinde benimsenen bir görüş olduğunu, AY-md. 138 ve 4721 say1lı Kanun-md.1/2 ${ }^{55}$ de yer alan hükümlerden ve vicdani kanaat ilkesinden yola çıkarak açıklamış, AY-md. 138'de yer alan "hukuk" kavramının "yargıcın genel ilkeler çerçevesinde yasal boşluğu doldurmak üzere oluşturacağl hükmü" de içerdiğini belirtmiştir ${ }^{56}$. Bu karara benzer nitelik taşıyan bir başka kararında da Anayasa Mahkemesi, "idari davalarda yargı yerinin yönlendirdiği kendine özgü yargılama yöntemi söz

47 D5D, E.2018/4681, K.2018/17806, KT. 29.11.2018; www.hukukturk.com; e.t.18.03.2021.

48 D6D, E.2005/6044, K.2005/5472, KT.15.11.2005; D10D, E.2010/814, K.2010/409, KT. 30. 04.11.2010;www.hukukturk.com; e.t.17.03.2021.

49 Bkz. HMK-md. 114.

50 Bkz. HMK-md. 303.

51 Bkz. HMK-md. 165, CMK-md. 218.

52 Medeni Kanun, RGT. 08.12.2001, RGS. 24607.

53 D12D, E.2013/725, K.2013/8623, KT.26.11.2013; www.hukukturk.com; e.t.21.03.2021.

54 DİDD, E.2010/2108, K.2013/4577, KT.16.12.2013; www.hukukturk.com; e.t.21.03.2021.

554721 Say1lı Kanun -md.1/2: "Kanunda uygulanabilir bir hüküm yoksa, hâkim, örf ve âdet hukukuna göre, bu da yoksa kendisi kanun koyucu olsaydı nasil bir kural koyacak idiyse on a göre karar verir."

56 AYM, E.1993/33, K.1993/0, KT. 21.10.1993; www.hukukturk.com; e.t.18.03.2021. 
konusu” olduğunu ve AY-md. 138'de yer alan kuralın, "hâkimin hükmünü verebilmesi için ne gibi önlemler almak gerekli ise, bunların tümünü içerdiği" ni belirtmiştir ${ }^{57}$.

Bununla birlikte, IYYUK-md. 31'de 1slah kurumuna atıf yapılmamış olması sebebiyle söz konusu madde hükmünün anayasaya aykırılığı hususunda yapılan itirazda bu kez Anayasa Mahkemesi, IYUK-md 31'e atıf yapılmaması sebebiyle 1slah kurumunun idari yargılama usulünde uygulama alanı olmadığını belirtmiş ve yine kararına gerekçe olarak idari yargının kendine özgü kuralları ve yargılama yöntemleri olduğunu ve bu husustaki düzenlemenin ise yasa koyucunun takdirinde olduğunu belirterek, bu kararda aynı zamanda idari yargılama usulünde yer verilmemiş kurumlara örnek olarak tanık kurumunu da göstermiştii ${ }^{58}$. Görüldüğü gibi, üst paragraftaki kararın aksine Anayasa Mahkemesi, IYYUK-md. 31'de yer almayan hususlarda HMK hükümlerinden yararlanılamayacağ şseklinde hüküm kurmuştur. $\mathrm{Bu}$ kararın verilmesinin ardından, İYUK-md. 16/4'e eklenen cümle ${ }^{59}$ ile idari yargılama usulünde davacının dava dilekçesinde belirtmiş olduğu miktarı artırabilmesine yönelik hüküm eklenmiş ve böylelikle, davacının örneğin bilirkişi raporu doğrultusunda davasını 1slah edememesi gibi hakkaniyete aykırı uygulamalara yol açabilme potansiyelinde olan hukuksal boşluk doldurulmuştur. Davanın taraflarının sözlü beyanına ihtiyaç duydukları tanıklarını mahkeme huzurunda dinletememesi durumu açısından da bu yönde bir kanun değişikliğine gidilmesi şüphesiz çok olumlu olacaktır. Bununla birlikte, kanun değişikliği olmasa da aşağıda açıklanacağ üzere idari yargılama usulünde gerekli olan hallerde tanık dinlenmesi mümkündür.

\section{IYUK'ta Yer Alan Delillere İlişkin Diğer Hükümler Karşısında}

Yargılama sırasında başvurulacak deliller ile ilgili olarak CMK ve HMK'nin aksine, IYUK' ta çok sınırlı hükümlere yer verilmiştir. İYUK-md. 31'de sadece bilirkişi ve keşif delilleri ile delillerin tespiti hususunda HMK'ye atıf yapılmış, IYYUK-md. 58'de delillerin tespiti ayrıca düzenlenmiştir. Bunlar dışında, IYYUK-md. 3/b'de dava dilekçesinde bulunması gere-

57 AYM, E.1990/40, K.1991/33, KT. 01.10.1991; www.hukukturk.com; e.t.18.03.2021.

58 AYM, E.2004/103, K.2008/121, KT.12.06.2008; www.hukukturk.com; e.t.17.03.2021.

59 IYUK-md. 16/4: “...(Ek Cümle: 11/4/2013-6459/4 md.) ancak, tam yargı davalarında dava dilekçesinde belirtilen miktar, süre veyadiğer usul kuralları gözetilmeksizin nihai karar verilinceye kadar, harcı ödenmek suretiyle bir defaya mahsus olmak üzere artırtlabilir ve miktarın artırlmasına ilişkin dilekçe otuz gün içinde cevap verilmek üzere karşı tarafa tebliğ edilir." 
ken hususlar arasında "Davanın konu ve sebepleri ile dayandı̆̆ deliller" sayılmış ve davacının dava dilekçesi ekinde sunacağı delillerle ilgili olarak herhangi bir istisnaya yer verilmemiştir. IYYUK-md. $16 / 5^{\prime}$ te ise, dava konusu işlem dosyalarının aslının ya da onaylı örneğinin idarenin savunması ile birlikte verilmesi gerektiği belirtilmiş; böylece hem davacı açısından hem de davalı açısından delil sunulması gerekliliği kanunen benimsenmiştir. Bunun dışında dava konusu maddi olayı ispata yarayan delillerin hangi deliller olacağına ve bu delillerin tabi olacağı hukuki rejime ilişkin ayrıca ve açıkça düzenleme yapılmamıştır. Bu doğrultuda, IYYUK'ta delillerin açıkça belirtilmemiş olmasının ${ }^{60}$ ve İYUK-md. 20/1'de yer alan resen araştırma ilkesinin, idari yargılama usulünde delil serbestliğinin geçerli olduğu anlamına geldiği kabul edilmektedir ${ }^{61}$.

Böylelikle, her ne kadar IYUK-md. 31'de tanık delili ile ilgili olarak HMK'ye atıf yapılmamış olsa da IYYUK-md.3/b'de davacının sunacağı delillerle, IYYUK-md. 16 başta olmak üzere IYYUK'un diğer hükümlerinde davalı idarenin sunacağı delillerle ilgili olarak sınırlama yapılmamış olması, idari yargılama aşamasında tanık dinlenmemesinin haklılığını ortadan kaldırmaktadır. Davanın taraflarının dava ya da cevap dilekçelerinde duruşma talep etmesi ve tanıklarının ismini belirtmeleri durumunda ya da keşif sırasında tanıklarını dinletmeyi talep etmeleri durumunda, IYYK'ta tanık delili ile ilgili bir yasak bulunmaması ve keşif sırasında tanık dinlenmesi ile ilgili olarak ise IYYUK-md. 31'de HMK'ye atıf yapılmış olmasına dayanarak, idari yargılama aşamasında tanık dinlenmesi mümkün olabilir. Yine, yargılama aşamasında ihtiyaç duyulması halinde, aşağıda açıklanacağı üzere resen araştırma ilkesi doğrultusunda ve gerektiğinde CMK hükümlerinden yararlanmak suretiyle idari hâkimin resen tanık dinlenmesine karar vermesinin de mümkün olduğu söylenebilir. Doktrinde, hukuk yargılamasında başvurulan delillerden, idari yargılama usulünde davanın niteliğine göre faydalanılabilecek deliller arasında tanık delili de gösterilmiştir ${ }^{62}$. Kaldı ki, idari yarg1lama usulünde ikrar, kesin hüküm ve yazılı belge kesin deliller, bilirkişi ve keşif ise takdiri deliller arasında kabul edilmektedir ${ }^{63}$. Bununla birlikte, örneğin ikrarla ilgili olarak ne IYUK'ta düzenleme bulunmakta ne de HMK'ye atıf yapılmaktadır.

\footnotetext{
Ceylan, s. 326.

61 Gözübüyük, A. Şeref/Tan, Turgut: İdare Hukuku Cilt II, Güncelleştirilmiş 7. Bask1, Turhan Kitabevi, Ankara, 2014, s. 948.

62 Onar, s. 1980.

63 Yasin, s. 100.
} 
Görüldüğü gibi, gerek Danıştay'ın gerek Anayasa Mahkemesi’nin boşluk durumunda diğer usul kanunlarındaki hükümlerden yararlanılıp yararlanılamayacağı hususundaki çelişkili kararları gerek IYYUK'ta delillere ilişkin düzenlemeler birlikte değerlendirildiğinde, idari yargılama aşamasında tanık dinlenmemesine gerekçe olarak gösterilen IYUK-md. 31 hükmü hukuki bir gerekçe olmaktan uzaklaşmaktadır. Böylelikle, IYYUK-md. 31'de tanık delili ile ilgili olarak HMK'ye atıf yapılmamış olması, idari yargılama aşamasında gerekli durumlarda tanık dinlenebilmesine engel bir hüküm değildir.

\section{Resen Araştırma İlkesinin Tanık Dinlenmesi Açısından Uygulanabilirliği}

Doktrinde, idari yargılama usulünde diğer delillerle tam bir sonuca ulaşılamayan uyuşmazlıklarda tanık dinlenmesinin bir gereklilik olduğu ve IYYUK-md. 20/1'de düzenlenmiş olan resen araştırma ilkesinin tanık delili açısından başvurulabilecek bir ilke olduğu belirtilmektedir ${ }^{64}$. Doktrinde ayrıca, idari yargılamada, hukuk yargılamasından farklı olarak, yargılamanın amacının sadece taraflar arasındaki uyuşmazlığı çözmek olmayıp aynı zamanda idarenin hukuka bağlı kalmasını sağlamak ve böylece hukuk devletini gerçekleştirmek işlevleri de bulunmasının, idari yargılama usulünde ispat sürecini kendine özgü hale getirdiği ve mahkemenin ispat sürecine resen araştırma ilkesi doğrultusunda katılmakta olduğu belirtilmektedir ${ }^{65}$. Bununla birlikte Danıştay, resen araştırma ilkesinin tanık dinlenmesini ya da ifade alınmasını içermediğini belirtmektedir ${ }^{66}$.

Görüldüğü gibi, Danıştay IYYUK-md. 20/1'de yer alan resen araştırma ilkesini de tanık dinlemek için başvurulabilecek bir hüküm olarak kabul etmemektedir. Hukuk ve ceza yargılamalarında ise tanık deliline sıklıkla başvurulmakta ve bu delil, takdiri bir delil olmasına rağmen hukuk yargilamasında vazgeçilmez deliller arasında ${ }^{67}$, ceza yargılamasında da yargılamanın en önemli ispat araçlarından biri olarak ${ }^{68}$, kabul edilmektedir. Böylelikle hem hukuk yargılamasında hem de ceza yargılamasında başvurulan ve

64 Çağlayan (Tanık), s. 202; Çağlayan, Ramazan: İdarî Yargılama Hukuku, Güncellenmiş 9. Baskı, Seçkin Yayıncılık, Ankara, 2017, s. 393. Aynı yönde görüş için bkz.; Çınarlı /Azak, s. 511.

65 Yasin, s. 7-12.

66 D8D, E.2003/3369, K.2004/917, KT.25.02.2004; www.hukukturk.com; e.t.03.03.2021.

67 Karamercan, Fatih: "Medenî Usûl Hukukunda Tanık ve Tanıklık", Ankara Barosu Dergisi, Say1 3, 2018, s. 154.

68 Badem, Semiyet: “Ceza Muhakemesi Hukukunda Tanık”, Türkiye Adalet Akademisi Dergisi, Say1 45, Y1l 12, 2021, s. 289. 
hukuk yargilamasında takdiri deliller ${ }^{69}$, ceza yargilamasında ise beyan delilleri $^{70}$ arasında kabul edilen tanık deliline, ceza ve hukuk yargılamasının karışım ${ }^{71}$ niteliğinde olan idari yargılama usulünde yer verilmiyor olması önemli bir eksikliktir. Oysa, IYUK-md. 20/1'de resen araştırma ilkesinin benimsenmiş olması ile IYYUK'ta tanık delilini yasaklayan bir hüküm bulunmuyor olması ve Danıştay'ın boşluk durumunda HMK hükümlerinden yararlandığı kararları, Türkiye'de idari yargılama aşamasında tanık dinlenebilmesinin hukuki nedenleri olarak kabul edilebilir.

Danıştay'ın her ne kadar yargılama sırasında boşluk durumunda CMK hükümlerini uygulamış olduğu bir kararına ulaşılamamış olsa da idari yargılama usulünde geçerli resen araştırma ilkesinin, idari yargı hâkiminin ihtiyaç duyulan uyuşmazlıklarda CMK'nin tanığa ilişkin hükümlerinden yararlanmasının da hukuki dayanağını oluşturduğu söylenebilir. CMK'nin tanığa ilişkin hükümlerine başvurulması durumunda HMK'deki uygulamanın aksine, davanın taraflarınca talep edilmese de hâkim tarafindan resen tanık dinlenilmesine karar verilmesi mümkün olabilecektir. Zira, hukuk yargılamasında tanıklar davanın taraflarınca gösterilmekte ve tarafların tanık olarak göstermedikleri kişileri, mahkeme resen tanık olarak dinleme olanağına sahip bulunmamaktadır ${ }^{72}$. Gerçi, doktrinde HMK-md. 31'de düzenlenmiş olan hâkimin davayı aydınlatma ödevi doğrultusunda, hâkimin “... dava dosyasına usulüne uygun biçimde girmiş olan belgelerde isimleri yazll olan kişileri kendiliğinden tanık olarak..." dinleyebileceği belirtilmiştir ${ }^{73}$. İdari yargılama usulünde de idarenin işlem dosyasında adı geçen kişiler açısından, hukuk yargılamasındaki bu yaklaşımın benimsenebileceği söylenebilir. Bununla birlikte, hukuk yargılamasında kural olarak tasarruf ilkesi ve bu ilkenin tamamlayıcısı niteliğinde olan taraflarca getirilme (hazırlama) ilkesi benimsenmiş, resen araştırma ilkesine ise HMK- md. 385/2 gereği çekişmesiz yargı işlerinde ve çekişmeli yargıda ise babalık davası ya da evlenmenin

69 Kuru, s. 242.

70 Yenisey, Feridun/Nuhoğlu, Ayşe: Ceza Muhakemesi Hukuku, Güncellenmiş 8. Bask1, Seçkin Yayıncıllk, Ankara, 2020, s. 518.

71 Özay, İl Han: Günışığında Yönetim II Yargısal Korunma, Filiz Kitabevi, İstanbul, 2004, s. 40.

72 Kuru, s. 301; HMK-md. 240/2: "Tanık gösteren taraf, tanık dinletmek istediği vakıayı ve dinlenilmesi istenen tanıkların adı ve soyadı ile tebliğe elverişli adreslerini içeren listeyi mahkemeye sunar. Bu listede gösterilmemiş olan kimseler tanık olarak dinlenemez ve ikinci bir liste verilemez."

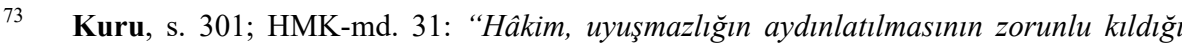
durumlarda, maddi veya hukuki açıdan belirsiz yahut çelişkili gördüğü hususlar hakkında, taraflara açıklama yaptırabilir; soru sorabilir; delil gösterilmesini isteyebilir." 
butlanı davası örneklerinde olduğu gibi sınırlı sayıdaki dava türlerinde istisnai olarak yer verilmiştir ${ }^{74}$. Hukuk yargılamasında kural olarak benimsenmiş olan taraflarca getirilme (hazırlama) ilkesi, delilleri de kapsamakta ve kural olarak delillerin davanın taraflarınca sunulmasını ve hâkimin kendiliğinden delil toplayamamasını ifade etmektedir ${ }^{75}$. Ceza yargılamasında ise amaç maddi gerçeğin araştırılması olduğundan, hâkimin tarafların sunmuş olduğu delillerle bağlı tutulamayacağı, CMK-md. 163 doğrultusunda soruşturma aşamasında hâkimin delil araştırma ödevi olduğu, bununla birlikte mülga $\mathrm{CMUK}^{76}$-md. 237/son'da kovuşturma aşamasında mahkemenin resen delil toplaması hakkında düzenleme bulunmasına rağmen CMK-md. 206 gereği kovuşturma aşamasında hâkimin resen delil toplama hakkı olmadığ ${ }^{77}$ belirtilmektedir. Bununla birlikte, doktrinde CMK ile mülga CMUK arasindaki bu düzenleme farkına rağmen hâkimin resen araştırma ve delil toplama yetkisinin devam ettiğ $\mathrm{i}^{78}$ ve uygulamanın ${ }^{79}$ da bu yönde olduğ ${ }^{80}$, belirtilmektedir. Bu durumda, hukuk ve ceza yargılamasının karışımı niteliğinde olan idari yargılama usulünde HMK'nin hâkimin aydınlatma ödevi doğrultusundaki hükümleri ile ceza yargılamasında geçerli resen araştırma ilkesinin sentezi yapılarak, özellikle, çalışmanın ikinci bölümünde tekrar belirtileceği gibi, idari usul sürecinde dinlenmiş olan tanıkların yargılama sırasında sözlü olarak dinlenmesi ihtiyacı doğduğunda, davanın taraflarınca tanık dinlenmesi talep edilmiş olmasa da mahkemece resen tanık dinlenmesine karar verilebileceği söylenebilir.

\section{E. İdari Yargılama Usulünde Tanık Deliline Duyulan İhtiyaç}

İdari yargılama sırasında tanık dinlenmesi Danıştay tarafından kabul edilmemekte olsa da uygulamada tanık deliline duyulan ihtiyaç ortaya kon-

\footnotetext{
$74 \quad$ Kuru, s. 211, 213.

75 Kuru, s. 212.

76 Ceza Muhakameleri Usulü Kanunu, RGT. 20.04.1929, RGS. 1172.

77 Yenisey/Nuhoğlu, s. 512.

78 Gedik, Doğan: "Ceza Muhakemesinde Hakimin Delilleri Değerlendirme Serbestliği (CMK m. 217)”, Dokuz Eylül Üniversitesi Hukuk Fakültesi Dergisi, Prof. Dr. Durmuş TEZCAN'a Armağan, Cilt 21, Özel Say1, 2019, s. 940-941.

79 Örnek için bkz. “...Resen araştırma ilkesi uyarınca mahkemeler, Cumhuriyet savcısının ortaya koyduğu delillerle bağlı olmadikları gibi, savcı olmasa bile kendiliklerinden, hüküm için gerekli tüm araştırmaları yapmak ve tarafların haklarını korumak zorundadirlar...” ; AYM, E. 2011/43, K. 2012/10, KT. 19.01.2012; “...kovuşturma evresinde mahkemenin delil toplamasina yasal bir engel de yoktur...”; Y18CD, E. 2015/23541, K. /1980, KT.28.05.2015; Gedik, s. 941, dipnot 113.

80 Gedik, s. 941.
} 
maktadır. Türkiye'de tanık dinleme gerekliliği ile ilgili olarak, avukatlar, hâkimler, Danıştay ve (Kaldırılan) Askeri Yüksek İdare Mahkemesi mensupları arasında yapılan bir anket sonucuna göre tanık dinleme gerekliliğinin ortaya konmuş olduğu ve bu sebeple en kısa zamanda gerekli değişikliklerin yapılması gerektiğ $i^{81}$, belirtilmiştir. Söz konusu anket çalışmasında idari yargıda tanık ifadesinin ne derece gerekli olduğuna ilişkin soruya, avukatların orta derecede, hâkimlerin ve Danıştay üyelerinin ise az derecede gerekli olduğu yönünde cevap vermiş olmaları sebebiyle, tanık deliline olan ihtiyacın uygulamada doktrindeki gibi değerlendirilmediği belirtilmiştir ${ }^{82}$. Bununla birlikte, tanık dinlenmesi ile ilgili olarak içtihadından dönüş yapmamış olan Danıştay üyelerinin, sorulan soruya " $a z$ " şekilde bile cevap vermiş olması, bazı uyuşmalıklarda tanık dinlenmesine ihtiyaç duyulduğunu ortaya koymaktadır.

Doktrinde ayrıca, gerek sınır uyuşmazlıkları ile ilgili olarak ${ }^{83}$ keşif sırasında mahalli bilirkişi adı ile de olsa tanık dinlenmesi gerek duruşmalı davalarda idari yarg1 yerleri tarafindan genellikle idare vekilinin yanında, dava konusu hakkında bilgi sahibi olan teknik elemanların da dinlenerek bu kişilerin açıklamalarının kararlarda dikkate alındığı belirtilmiş ve bu uygulama idari yarg1 yerlerinin, idari yargilama usulünde tanık dinlenmesine engel olan pozitif hukuk hükümleri ve fakat tanık dinleme ihtiyacının giderilmesine yönelik uygulamalarına örnek olarak gösterilmiş ${ }^{84}$; vergi uyuşmazlıkları ile ilgili olarak kanun koyucunun da bu ihtiyacı duyduğu ve VUK'a mükerrer 378. madde hükmünün eklenmiş olduğu belirtilerek, İYUK'a idari yargılama aşamasında tanık dinlenebilmesi imkânı tanıyan hükümlerin eklenmesinin "adaletin tecellisine yardımcı olaca ̌̆ Yine, bazı idari yargı kararlarında, her ne kadar yargılama aşamasında tanık dinlenmemiş olsa da dava ile ilgili bilgisi bulunan kişilerin dosyaya sunulan yazılı beyanlarına dayanılarak karar verilmiştir ${ }^{86}$.

81 Akıncı, Müslüm: İdari Yargıda Adil Yargılanma Hakkı, Turhan Kitabevi, Ankara, 2008, s. 260.

82 Yılmaz (Sözlülük), s. 309-310.

83 Sınır uyuşmazlıklarına ilişkin bazı idari yargı kararlarında, her ne kadar tanık değil mahalli bilirkişi ifadesi kullanılmış olsa da, keşif sırasında tanık dinlenmesinin önemi ortaya konmuştur. Örnek İçin bkz. D9D, E.1992/193, K.1992/2430, KT.11.11.1992; www.hukukturk.com; e.t.03.03.2021.

84 Hondu, s. 263-264.

85 Hondu, s. 264-265.

86 Örnek olarak, Konya İdare Mahkemesi'nin, E.1988/592, K.1988/964, KT.14.12.1988 tarihli kararı gösterilmiştir; Hondu, s. 263. 
Tüm bu açıklamalar, Danıştay'ın idari yargıda tanık dinlenmemesine yönelik yerleşik içtihadına rağmen, idari yargılama usulünde tanık dinlenmesine yönelik ihtiyacı gözler önüne sermekte olup; mevzuat değişikliği yapılmasa dahi aşağıda ayrıntılı olarak inceleneceği üzere adil yargılanma hakkı ve vicdani kanaat ilkesi ile yukarıda açıklanmış olduğu gibi İYUK-md. 20/1 hükmü, idari yargılama sürecinde tanık dinlenebilmesinin hukuki nedenleri olarak gösterilebilir. Kaldı ki, Danıştay'ın tanık dinlenmeyeceğine ilişkin buraya kadar açıklanmaya çalışılan içtihadı sınırlı sayıdaki bazı kararlarından oluşmaktadır. Bununla birlikte, idari yargılama sürecine dolaylı olarak, hatta bazen doğrudan etki eden ve fakat idari işlemin yapılış sürecinde ya da adli yargı yerlerince dinlenmiş olan tanık ifadeleri ise, Danıştay'ın çok sayıdaki kararına konu olmuştur. Bu sebeple, mahkemece dinlenmese de tanık delilinin idari yargılama aşamasında önemli bir delil olduğunun altı çizilmelidir.

\section{II. İDARİ USUL SÜRECINDE VE ADLİ YARGI YERLERINCE ALINMIŞ TANIK İFADELERINIIN İDARİ YARGILAMA SÜRECINNE DOLAYLI (DOĞRUDAN?) ETKISII}

\section{A. İdari Usul Sürecinde Alınmış Olan Tanık İfadelerinin İdari Yargılama Sürecine Dolaylı (Doğrudan?) Etkisi}

İdari usul, doktrinde idari işlem yapılmadan önce uygulanan, ilgililerin çağrılması ve dinlenmesi ile yargılama usulü benzeri bazı usulleri içeren ve idarenin işlemini yapmadan önce kendini denetlemesi imkânını da sağlayan bir süreç olarak tarif edilmiş ${ }^{87}$, bu sürecin soruşturma sürecini ifade ettiği ve taraflara iddia ve savunmada bulunma imkânı verdiği belirtilmişti ${ }^{88}$.

Danıştay da tanık delilini idari işlemin yapılış sürecinde yer verilmesi gereken bir usul işlemi olarak kabul etmekte, idari işlemin yapılış sürecinde alınan tanık beyanlarını birçok kararında gerekçe olarak kullanmakta ve bazı idari yaptırım kararlarının alınış sürecinde, tanık ifadesi alınması gerekliliğini vurgulamaktadır. Örneğin; çay ocağı ruhsatlı olarak işletilen işyerinin işyeri açma ve çalışma ruhsatının, kolluk güçleri tarafından gözleme dayalı olarak ve işyerinin ruhsat harici faaliyet gösterdiği tespitine dayalı olarak iptal edilmesine ilişkin idari işlem ile ilgili olarak Danıştay, ilgili kişilerin ve

87 Azrak, Ali Ülkü: Umumi İdari Usulün Teorik Esasları ve Çeşitli Hukuk Sistemlerinde Gelişimi, Doktora Tezi, İstanbul, 1964, s. 5-6'dan aktaran Akyılmaz, Bahtiyar: İdari Usul İlkeleri Işıı̆ında İdari İşlemin Yapılış Usulü, Ankara, 2000, s. 70.

$88 \quad$ Akyılmaz, s. 70-71. 
tanıkların ifadeleri alınmadığı için, somut bilgi ve belgeye dayanmayan söz konusu idari işlemin hukuka aykırı olduğuna karar vermiştir ${ }^{89}$.

İdari usul sürecinde alınan tanık ifadeleri doğrultusunda verilen Danıştay kararları en çok disiplin cezalarına ilişkin uyuşmazlıklara ilişkin olmakla birlikte kanunlarında idari işlem yapılmadan önce soruşturma usulü getirilmiş olan başka bazı uyuşmazlık örnekleri de bulunmaktadır. Böylece, idari yarg1 yerleri her ne kadar yargılama sırasında tanık dinlememe yönünde içtihat oluşturmuş olsa da idari usul sürecinde idare tarafından dinlenmiş olan tanık ifadelerini, bazı uyuşmazlıklarda delil olarak kullanmaktadır. Yazılı tanık ifadelerinin yargılama aşamasında önemli bir yer teşkil etmesi açısından, idari yargılamanın ceza yargılaması ile benzerlik taşıdığı söylenebilir. Zira, ceza yargılamasında beyan delilleri arasında kabul edilen tanık beyanı, mahkemeye yapılan tanıklığ ifade etmekte, bunun dışındakiler ifade adını alarak, ifadeler tutanağa geçirildiğinde ise belge delili niteliğini haiz olmaktadır $^{90}$. Belge delilinin sağlamlık değerinin, söz konusu belgeyi düzenleyen kişinin güvenilirlik düzeyine göre değişeceği, bununla birlikte genellikle olay anında hazırlanmış olduğu için içerik bakımından sağlamlığının beyan delilinden çok daha fazla olduğu ceza yargılamasında kabul edilmektedir $^{91}$. Bununla birlikte, iki yargılama düzeni arasındaki temel fark, idari yargılama usulünde, yargılama aşamasında önceden ifadesi alınmış olan tanıklar dâhil hiç kimse tanık olarak dinlenemezken, ceza yargılamasında önceden ifadesi alınmış kişiler de dâhil olmak üzere tanıkların sözlü ifadelerinin oldukça önemli bir delil olarak kabul edilmesidir. CMK-md. $212^{\prime} \mathrm{de}^{92}$ yer alan ve tanığın duruşmadan önceki ifadesinin duruşma sırasında okunmasına ilişkin hükmün de mahkeme sırasında tanığın bir kez daha dinlenmesinin önemini ortaya koymakta olduğu söylenebilir.

\section{Disiplin Soruşturması Sırasında ve Soruşturma İzni Sürecinde Alınan Tanık İfadeleri}

Danıştay kararları incelendiğinde, Danıştay'ın dolaylı olarak yararlandığı tanık ifadelerinin en çok disiplin soruşturmalarına ilişkin uyuşmazlıklarda söz konusu olduğu görülmüş̧ür. Bu durumun, disiplin soruşturmala-

\footnotetext{
D8D, E.2002/5326, K.2003/2258, KT.14.05.2003; www.hukukturk.com; e.t.03.03.2021

Yenisey/Nuhoğlu, s. 519.

Yenisey/Nuhoğlu, s. 544.

CMK-md. 212: “ (1) Tanık, bir hususu hatırlayamadığını söylerse önceki ifadesini içeren tutanağın ilgili kısmı okunarak hatırlamasına yardım edilir. (2) Tanığın duruşmadaki ifadesiyle önceki ifadesi arasında çelişki bulunduğunda, evvelce alınmış ifadesi okunarak çelişkinin giderilmesine çalışılır."
} 
rında tanık dinleme yetkisinin mevzuatta açıkça soruşturmacıya verilmiş olmasından kaynaklanmakta olduğu düşünülebilse de doktrinde, idari karar alma sürecinde mevzuatta usul kuralı olarak tanık dinlenmesi yer almasa dahi idarenin tanık dinleyebileceğ $i^{93}$ ve soruşturmacının gerek görmesi halinde tanık dinleyebileceği belirtilmektedir ${ }^{94}$. Kamu görevlileri ile ilgili olarak Danıştay, disiplin soruşturmaları dışında, soruşturma izni sürecinde de yapılması gerekenler arasında varsa tanık ifadelerinin alınmasına yer vermekte $^{95}$; soruşturma konusu ile ilgili kişilerin tanık sıfatıyla ifadelerine başvurulmadan ve böylece eksik incelemeyle alınan rapora dayanılarak verilmiş olan lüzum-u muhakeme kararının verilmesine ilişkin kararları bozmakta$\mathrm{dir}^{96}$.

Disiplin hukukunda, tanık ifadesi ispat araçlarından biri olarak kabul edilmekte ve tanık, "soruşturulan memur ve soruşturmayı yürüten idare dlşında kalan üçüncü kişi” olarak tanımlanmaktadır ${ }^{97}$. Ceza yargılamasında tanıklık, "yargılanan uyuşmazlığın objesi olan fiili doğrudan doğruya beş duyusu ile algılamış olan kişinin hafizasında kalan hususları kovuşturma evresinde mahkemeye anlatması" ve tanık beyanı davanın tarafları dışında ve fakat olaya tanık olmuş kişinin mahkeme huzurunda vermiş olduğu sözlü beyanı ${ }^{98}$ olarak tanımlanmaktadır. Hukuk yargılamasında tanık, davanın tarafları dışında olan ve dava konusu olayla ilgili olarak dava dışında elde etmiş olduğu bilgiyi mahkemeye bildiren kişis ${ }^{99}$, olarak tanımlanmaktadır. Görüldüğü gibi bu tanım, ceza ve hukuk yargılamasındaki tanık tanımına oldukça benzemektedir. Bununla birlikte, disiplin soruşturmalarında tanık dinlenmesi hususunda genel bir düzenleme bulunmamakta; bazı kanunlarda disiplin soruşturması sırasında soruşturmacının tanık deliline ${ }^{100}$ başvura-

93 Yasin, s. 45.

94 Sancakdar, Oğuz/Altınok Çalışkan, Elif/Dursun, Gizem/Seyhan, Serkan/Yağcı, Pınar: Disiplin Hukuku, Turhan Kitabevi, Ankara, 2019, s. 185.

95 “...soruşturmacının,...varsa tanıkların ifadelerini alması... gerekmektedir...”; D1D, E.2017/2375, K.2018/252, KT.01.03.2018; www.hukukturk.com; e.t.03.03.2021.

96 D1D, E.2010/199, K.2010/415, KT.10.03.2010; www.hukukturk.com; e.t. 03.03.2021

97 Sancakdar/Altınok Çalışkan/Dursun/Seyhan/Yağcı, s. 184-185.

98 Yenisey/Nuhoğlu, s. 518-519.

99 Kuru, s. 299

100 Örneğin, DMK-md. 129/1: “Yüksek disiplin kurulları kendilerine intikal eden dosyaların incelenmesinde, gerekli gördükleri takdirde, ilgilinin özlük dosyasını ve her nevi evrakı incelemeye, ilgili kurumlardan bilgi almaya, yeminli tanık ve bilirkişi dinlemeye veya niyabeten dinletmeye, mahallen keşif yapmaya veya yaptırmaya yetkilidirler.", 2547 Sayılı Kanun-md. 53/A-g: "Soruşturmacı, disiplin soruşturmaslyla ilgili bilgi ve belgeleri toplama, ifade alma, tanık dinleme, bilirkişiye başvurma, keşif yapma, inceleme yapma ve ilgili makamlarla yazışma yetkisini haizdir. ". 
bileceği belirtilmektedir ${ }^{101}$. Böylelikle, disiplin hukukunda tanığın dinlenme usul ve esaslarına ilişkin ortaya çıkan boşlukla ilgili olarak, HMK hükümlerinin değil CMK hükümlerinin kıyasen uygulanmasının daha uygun olabileceği doktrinde belirtilmektedir ${ }^{102}$. AİHM kararlarında ${ }^{103} \mathrm{da}$, ceza yargılamasındaki tanık dinletme hakkının disiplin hukukuna da kıyasen uygulanması gerektiği belirtilerek, tanık delilinin disiplin soruşturmalarındaki önemi vurgulanmıştır ${ }^{104}$.

Doktrinde, idari usul sürecinde bu kadar önemli bir yeri bulunan tanık delilinin, idari yarg1 yerlerince dolaylı olarak kullanılmasının doğrudanlık ilkesi ile çelişkili yönüne vurgu yapılmış, hâkimin delillere doğrudan temas etmesi gerektiği belirtilmiştir ${ }^{105}$. Aslında Danıştay da disiplin hukukunda soruşturma sırasında alınan tanık ifadelerinin önemini ortaya koymuş ve soruşturma raporlarının idari yargı yerleri için en önemli yargısal malzemeler arasında yer aldığını ve "fakat bu yargısal malzemelerin yargılama süresinde dikkate alınabilmesi ve yargılamayı yapan yargı yerlerinin soruşturma raporuyla saptanan hususları kararına dayanak yapabilmelerinin temel koşulu ise, bu raporların tarafsız olarak hazırlanmış olmasına bağlldır. "106 şeklinde hüküm kurarak, idarece dinlenen tanıkların beyanlarının tutanağa geçirilmesi sırasında bazı sorunlar olabileceğini kabul etmiştir. Söz konusu tutanakların ya da soruşturma raporunun tarafsız şekilde hazırlanıp hazırlanmadığının anlaşılabilmesinin en kesin yolu ise, kuşkusuz idari hâkim tarafindan şüpheye düşülen ya da taraflarca bu hususta talepte bulunulan hallerde, soruşturma sırasında idarece dinlenmiş olan tanıkların yargılama sırasinda da dinlenebilmesidir.

Danıştay bazı uyuşmazlıkların çözümünde, disiplin soruşturmalarında dinlenen tanık ifadelerini kararında delil olarak kullanmaktadır ${ }^{107}$. Bununla birlikte, disiplin soruşturmasında alınan tanık ifadelerinin çelişkili olduğuna ${ }^{108}$ ya da tanık ifadelerinin olayı açıklığa kavuşturamadığına ${ }^{109}$ karar

\footnotetext{
101 Sancakdar/Altınok Çalışkan/Dursun/Seyhan/Yağcı, s. 185.

102 Sancakdar/Altınok Çalışkan/Dursun/Seyhan/Yağcı, s. 187.

103 Örnek için bkz. Cihan Yeşil/Türkiye, BN. 2013/8635, KT. 06.05.2015'ten aktaran: Sancakdar/Altınok Çalışkan/Dursun/Seyhan/Yağcı, s. 236.

104 Sancakdar/Altınok Çalışkan/Dursun/Seyhan/Yağcı, s. 237.

105 Türkoğlu Üstün, s. 347.

106 D8D, E.2004/3334, K.2005/5118, KT.12.12.2005; www.hukukturk.com; e.t.03.03.2021.

107 D12D, E.2015/3879, K.2019/1581, KT.05.03.2019; www.hukukturk.com; e.t.03.03.2021.

108 D5D, E.2016/17798, K.2018/13132, KT.05.04.2018; D12D, E.2015/2468, K.2019/3436, KT. 08.05.2019; www.hukukturk.com; e.t.03.03.2021.
} 
verdiği uyuşmazlıklar ile tanık ifadelerinden sadece aleyhe olanların dikkate alınmış olması durumunda ${ }^{110}$, disiplin cezasına konu eylemlerin işlendiğinin "her türlü şüpheden uzak, kesin ve inandırıcı ya da somut, yeterli ve inandırıcı delillerle ortaya konulamadĭ̆ı" sonucuna ulaşmakta ve söz konusu tanık ifadelerine dayalı olarak verilen disiplin cezalarını hukuka aykırı bulmaktadır. Yine Danıştay, disiplin cezasına konu teşkil eden birden fazla fiil söz konusu olduğunda, bu fiillerin tümüne tanıklık edebilecek kişilerin ifadelerine başvurulmadan verilen disiplin cezasının hukuka aykırı olacağına karar vermiştir ${ }^{111}$. Hatta Danıştay, soruşturma dosyasında yer alan tanık ifadelerine dayanılarak verilmiş olan disiplin cezalarının hukuka aykırı olmadığına dair mahkeme kararlarının kesinleşmesinin ardından, söz konusu tanık ifadelerinin gerçekliği hususunda şüphe ortaya çıktığ takdirde davacı hakkında yargılamanın yenilenmesi yoluna başvurulması gerektiğine de karar vermiştir. Söz konusu kararlardan birinde; meslekten çıkarma disiplin cezasının biri okur-yazar olmayan, diğeri ise yeterince Türkçe bilmeyen tanık ifadelerine dayalı olarak verilmiş olmasıyla ${ }^{112}$, bir başka kararda ise meslekten çıkarma disiplin cezasına gerekçe teşkil eden tanık ifadelerinin, daha sonradan tanıkların adli yargıda alınan ifadelerinde eski ifadelerini baskı altında vermiş olduklarını belirtmiş olmalarıyla ${ }^{113}$ şüphe doğduğu kabul edilmiş ve her iki kararda şu gerekçelere yer verilmiştir: "Bu hususlar bir bütün olarak değerlendirildiğinde, hukuki menfaati etkilenen davact hakkında, adil yargılanma hakkı kapsamında hakkaniyetli bir sonuca ulaşılabildiği noktasında şüphe doğduğu ve bu kararın yukarıda hukuki değerlendirme başlığı altında irdelenen; delillerin büsbütün dayanaksı kalmasinı sağlayan ve kanunda sayılmış olan hallerin ortaya çıkması davanın esasının incelendiği zamanda mevcut olan hukuki delillerin ışı̆̆ında bulunmuş olan hukuk gerçeğinin, yargılamanin yenilenmesi yoluyla yeni delillere göre yeniden aranmasını gerekli kılmaktadır.". Bu karar, adil yargılanma hakkı açısından oldukça önemli bir karar olmakla birlikte, idari yargıda yeniden yapılacak olan yargılamada hâkimin şüpheye sebep olan tanıkları bizzat dinleyerek karar vermesinin usul ekonomisi ilkesine daha uygun olacağ

109 D12D, E.2017/2677, K.2018/722, KT.15.02.2018; D5D, E.2016/17534, K.2018/12871, KT. 29. 03. 2018; www.hukukturk.com; e.t.13.03.2021.

110 D5D, E.2016/18802, K.2018/13819, KT.03.05.2018; www.hukukturk.com; e.t.03.03.2021.

111 D12D, E.2012/2030, K.2015/6218, KT.26.11.2015; www.hukukturk.com; e.t.13.03.2021.

112 D5D, E.2018/2124, K.2019/1061, KT.13.02.2019; www.hukukturk.com; e.t 03.03.2021.

113 D5D, E.2018/2602, K.2019/929, KT.11.02.2019; www.hukukturk.com; e.t.03.03.2021. 
kuşkusuzdur $^{114}$. Avrupa Konseyi’ne üye olan bazı ülkelerde, idari yargılama aşamasında mahkemenin yazılı delilleri incelemeden önce hemen duruşmada tarafları, tanıkları ve bilirkişileri dinleyebilmelerine ilişkin "ivedilik prensibi” nin bir usul kuralı olarak kanunda yer aldığı ve sözlü duruşmada delillerin incelenmesinin bu ilkenin bir sonucu olduğ ${ }^{115}$, belirtilmektedir.

Görüldüğ̈̈ gibi, Danıştay disiplin soruşturmaları sırasında alınan tanık ifadeleri ile ilgili olarak oldukça özenli bir yaklaşım sergilemektedir. Bununla birlikte, davacının telefonla yaptığ 1 görüşmede söyledikleri hakkında ifade veren tek bir tanık ifadesine dayalı olarak verilmiş olan disiplin cezasını hukuka uygun bulması gibi, yukarıdaki paragrafta açıklanmış olan tutumu ile çelişen bazı kararları da bulunmaktadır. Örneğin, Danıştay yakın tarihli bir kararında, sadece tek bir tanık ifadesine dayanılarak verilmiş olan disiplin cezasının hukuka uygun olduğunu belirtmiştir. Bu kararda ilk derece mahkemesi ise, disiplin cezasına teşkil eden fiil konusunda okul müdürünün ifadesi dışında herhangi bir delil bulunmaması sebebiyle disiplin cezasının iptaline karar vermiştir ${ }^{116}$. Bu kararının aksine başka bir kararında ise Danıştay, telefondaki görüşmeye dayalı tanık ifadelerinin objektif olmadığına karar vermiştir ${ }^{117}$. Görüldüğü gibi, her iki uyuşmazlık oldukça benzer nitelikte olduğu halde ve hatta ikinci uyuşmazlıkta bir değil birden fazla tanık olduğu halde, ilk uyuşmazlıkta verilen disiplin cezası hukuka uygun kabul edilmişken, ikinci uyuşmazlıkta verilen disiplin cezası hukuka aykırı kabul edilmiştir. Oysa, her iki uyuşmazlık örneğinde, idari yarg1 sürecinde de disiplin soruşturması sürecinde dinlenmiş olan tanıklar tekrar dinlenmiş olsaydı, idari hâkim tarafından karşılaştırma yapma imkânı doğarak, hakkaniyete daha uygun karar verilmesi mümkün olabilecekti.

\section{Diğer Bazı İdari İşlemlerden Önce Yapılan Soruşturmalarda Alınan Tanık İfadeleri}

İdari usulde soruşturma yapılması ve söz konusu soruşturma sürecinde tanık ifadelerinin alınması usulü sadece disiplin işlemlerine ilişkin olmayıp,

114 Bu hususta bkz. Yılmaz (Sözlülük), s. 289; Çınarlı/Azak, s. 532.

115 Zrvandyan, Arman: İdari Yargıda Avrupa Adil Yargılanma Standartlarına İlişkin Emsal Kararlar, 2021, s. 78; https://rm.coe.İnt/emsalkararlarkitabioption-2/1680a1cdb6; e.t.01.04.2021, (Kitap, Avrupa Birliği, Türkiye Cumhuriyeti ve Avrupa Konseyi tarafindan ortaklaşa finanse edilmekte ve Avrupa Konseyi tarafından yürütülmekte olan “İdari Yargının Etkinliğinin Artırılması ve Danıştayın Kurumsal Kapasitesinin Güçlendirilmesi Projesi" kapsamında basılmıştır.)

116 D12D, E.2015/5615, K.2019/987, KT.13.02.2019; www.hukukturk.com; e.t.03.03.2021.

117 D5D, E.2016/19592, K.2018/13359, KT.11.04.2018; www.hukukturk.com; e.t.03.03.2021. 
başka bazı idari işlemlerde de bu süreç uygulanmaktadır. Bu örneklerden Danıştay kararlarına en çok konu olanlar; 3091 sayılı Kanun ${ }^{118}$ da ve Terör ve Terörle Mücadeleden Doğan Zararların Karşılanması Hakkında Yönetmelik (Yönetmelik) ${ }^{119}$ 'te belirtilmiş usule ilişkin olanlardır.

3091 sayılı Kanun-md.2 ve md.5 hükümleri gereğince, taşınmaz mallara tecavüz veya müdahale edilmesi halinde; ilgili kişinin yetkili idareye başvurusu üzerine, öncelikle yerinde soruşturma yapılarak, tecavüzün veya müdahalenin önlenmesine karar verilmesi ve taşınmaz malın yerinde zilyedine teslim edilmesi gerekmektedir. Soruşturma aşamasında, tanık ifadelerinin oldukça önemli bir yeri bulunmakta olup, 3091 sayılı Kanun'un 6. maddesinde soruşturma sırasında tarafların tanıklarının dinlenmesi hususu açıkça belirtilmiştir. 3091 sayılı Kanun'da öngörülmüş olan usul, Danıştay kararlarında da vurgulanmaktadır. Danıştay, tanık dinlenmeden yapılan soruşturmanın usule aykırı olduğuna ve böyle bir soruşturma sonucuna dayanarak verilen kararın hukuka aykırı olduğuna karar vermektedir ${ }^{120} .3091$ sayılı Kanun'dan önce yürürlükte olan 5917 sayılı Kanun ${ }^{121}$ çerçevesinde alınmış olan men kararına ilişkin uyuşmazlıkta da Danıştay-5917 sayılı Kanun-md.5'te her ne kadar soruşturma yapılması öngörülmüssse de tanık dinlenmesine ilişkin bir hüküm bulunmamasına rağmen- men kararının usulüne uygun olarak tanık dinlenmek suretiyle yapılan soruşturma sonucu verilmiş, hukuka uygun bir karar olduğuna karar vermiştir ${ }^{122}$.

Bu hususta Danıştay kararlarına yansıyan diğer örnek ise, terör zararlarının karşılanmasına ilişkin idari işlemler yapılmadan önceki usuldür. Terör ve Terörle Mücadeleden Doğan Zararların Karşılanması Hakkında Yönetmelik-md. 11'de, zarar tespit komisyonun gerek görmesi halinde keşif yapabileceği ve yine başvuru sahibinin varsa tanıklarının da keşif mahallinde hazır bulunacağı belirtilmiştir. Bu hüküm her ne kadar, zarar tespit komisyonuna takdir yetkisi tanımış olsa da Danıştay zarar tespit komisyonunun keşif yapmadan ve tanık dinlemeden vermiş olduğu kararları, eksik inceleme sonucu verilmiş, hukuka aykırı kararlar olarak kabul etmektedir ${ }^{123}$.

118 Taşınmaz Mal Zilyedliğine Yapılan Tecavüzlerin Önlenmesi Hakkında Kanun, RGT. 15.12.1984, RGS. 18606.

119 RGT. 20.10.2004, RGS.25619.

120 D10D, E.1996/5002, K.1998/4770, KT.12.10.1998; www.hukukturk.com; e.t.03.03.2021.

121 Gayrimenkule Tecavüzün Def'i Hakkında Kanun, RGT. 24.04.1952, RGS.8093.

122 D10D, E.1982/3982, K.1983/383, KT.24.02.1983; www.hukukturk.com; e.t.03.03.2021.

123 D15D, E.2014/6389, K.2018/6498, KT.27.09.2018; www.hukukturk.com; e.t.03.03.2021. 
Böylelikle, Danıştay sadece kanunda açıkça düzenlenmiş olan durumlarda değil, kanunda açıç̧a düzenleme bulunmayan hallerde de idari işlemin yapılış aşamasında tanık ifadesi alınması gerekliliğini kabul etmektedir.

\section{B. Adli Yargıda Alınan Tanık Beyanlarının İdari Yargılama Sürecine Dolaylı (Doğrudan?) Etkisi}

Adli yargıda alınan tanık ifadeleri, idari usul sürecinde alınan tanık ifadelerinden, tanıkların idare tarafından değil, yargı makamı tarafından dinlenmiş olması sebebiyle farklılaşsa da söz konusu ifadeler idari yargılama konusu uyuşmazlığa ilişkin dava dosyasında bulunan yazılı ifadeler olduğundan, idari usul sürecinde alınan tanık ifadeleri ile benzer nitelik taşımaktadır.

Danıştay, bazı uyuşmazlıklarda ceza yargılaması sırasında alınan tanık ifadelerini delil olarak kullanmaktadır. Bu uyuşmazlıklardan birinde Danıştay, ceza yargılamasında dinlenmiş olan tanık ifadeleri doğrultusunda dava konusu idari işlemin hukuka aykırı olmadığına karar vermiştir ${ }^{124}$. Başka bir uyuşmazlıkta Danıştay, ceza yargılamasında dinlenmiş olan tanıkların ifadelerinin vergi mahkemesince incelenmeksizin karar verilmiş olmasını hukuka aykırı bulmuştur ${ }^{125}$. Bir başka uyuşmazlıkta ise Danıştay, aynı fiille ilgili olarak disiplin soruşturmasında alınan tanık ifadeleri ile ceza yargılaması aşamasında dinlenen tanıkların ifadelerinin birbirinden farklı olması sonucu ortaya çıkan şüphe sebebiyle ve disiplin hukukuna hâkim olan "şüpheden sanık yararlanır" ilkesi gereğince, davacı hakkında verilmiş olan disiplin cezasının hukuka aykırı olduğuna karar vermiştir ${ }^{126}$. Bölge İdare Mahkemeleri de ceza mahkemelerince alınmıș olan tanık ifadelerini istinaf başvurusuna konu incelemeyi yaparken delil olarak kullanmaktadır ${ }^{127}$. Bununla birlikte Danıştay'ın, disiplin soruşturması sürecinde isnat edilen fiille ilgili tanık ifadesi alınmadan ve sadece adli soruşturma aşamasında alınan tanık ifadelerine dayalı olarak verilen disiplin cezasının hukuka aykırı olduğuna dair ${ }^{128}$ kararları da bulunmaktadır. Aslında, Danıştay'ın bu yöndeki kararlarının dahi, idari yargılama aşamasında tanık dinlenmesinin gereklili-

124 D10D, E.2014/2874, K.2019/167, KT.10.01.2019; www.hukukturk.com; e.t. 03.03.2021

125 D7D, E.1989/2023, K.1990/1523, KT.28.05.1990; www.hukukturk.com.03.03.2021.

126 D12D, E.2016/7260, K.2017/2823, KT.30.05.2017; www.hukukturk.com.03.03.2021.

127 Ankara BİM, 2.IDD, E.2018/2694, K. 2019/849, KT.26.04.2019; www.lexpera.com; e.t. 22. 03. 2021.

128 D5D, E.2016/10141, K.2016/4886, KT.24.10.2016; www.hukukturk.com; e.t. 03.03.2021. 
ğini ortaya koyduğu söylenebilir. Zira, bu kararları ile Danıştay tanık ifadelerinin değişebileceğini de kabul etmektedir. Bu durumda, gerekli olan durumlarda tarafların tanıklarının, uyuşmazlık hakkında karar verecek olan hâkim tarafından bizzat dinlenmesi, tanık ifadelerindeki çelişkilerin bizzat hâkim tarafindan fark edilebilmesi açısından oldukça önemlidir.

Görüldüğü gibi, Danıştay'ın idari yargılama usulünde tanık dinlenemeyeceğine ilişkin kabulü, aslında İYUK'ta mahkeme huzurunda tanık dinlenebileceğine ilişkin bir hüküm bulunmamasından kaynaklanmaktadır. Bununla birlikte, kanunda belirtilmiş olsa da olmasa da başta disiplin soruşturmaları olmak üzere birçok idari işlemin yapılış usulü aşamasında ve adli yargı yerlerince dinlenen tanık ifadelerini, Danıştay uyuşmazlıkların çözümünde çok defa delil olarak kullanmakta; böylelikle tanık ifadeleri mahkeme huzurunda alınmamış olsa da dolaylı olarak idari yargı yerinin vereceği karar1 etkilemektedir.

Kaldı ki, Danıştay kararlarında tanık kavramına ilişkin yapılan araştırmada, Danıştay ya da idari yargı yerlerince tanık dinlenmesinin kabul edilmemesine ilişkin sınırlı sayıda karar dışında karara ulaşmak mümkün olamamıştır. Bu durumda, davanın taraflarının tanık deliline ihtiyaç duymadıkları belki söylenebilse de davanın taraflarınca tanık dinlenmesinin talep edilmesi sonucu, Danıştay'ın tanık delili hususundaki içtihadında değişim belki gerçekleşebilecektir. Bu açıklamayla ilgili olarak yakın tarihli bir uyuşmazlıkta, Bölge İdare Mahkemesi'nden istinaf aşamasında duruşma ve tanık dinlenmesi talebinde bulunulmuş, Bölge İdare Mahkemesi ise tanık dinlenip dinlenemeyeceğine ilişkin herhangi bir açıklama yapmadan duruşma talebini reddetmiştir ${ }^{129}$. Böylelikle, her ne kadar son tahlilde tanık dinlenmemiş ve dosyaya sunulmuş olan tanık ifadeleri doğrultusunda karar verilmiş olsa da idari yargılama sürecinde tanık dinlenemeyeceğine ilişkin bir açıklama yapılmamış olması bile aslında, idari yargılama usulünde tanık dinlenebilmesi noktasında olumlu bir gelişme olarak yorumlanabilir.

\section{TANIK DELILININ ADIL YARGILANMA HAKKI VE VICDANI KANAAT İLKESİ İLE İLIŞKISSI}

İdari yargılama aşamasında tanık dinlenmesinin kabul edilmemesi, adil yargılanma hakkının ihlal edilmesine yol açabileceği gibi bazı durumlarda anayasal vicdani kanaat ilkesine de aykırı düşecektir. Bu durum, özellikle idari bir eylemin ya da yazılı olmayan bir idari işlemin ispatlanması örnek-

129 Ankara BİM, 13.İD, E.2020/3757, K. 2020/1687, KT.10.07.2020; www.lexpera.com; e.t. 22.03.2021. 
lerinde olduğu gibi, bazı uyuşmazlıklar açısından hakkaniyete aykırı sonuçlara yol açabilmektedir. Bu yaklaşım, adil yargılanma hakkına ve özellikle silahların eşitliği ilkesine aykırı bir uygulama olmakla birlikte, idari yargılama aşamasında tanık dinlenmezken, idari usul sürecinde alınan tanık ifadelerinin idari yargılama sırasında oldukça önemli deliller olarak kabul edilmesi çelişkili bir durum ortaya çıkarmaktadır. Diğer yandan, Danıştay özellikle disiplin soruşturmalarında alınan tanık ifadelerini vicdani kanaat ilkesi ile ilişkilendirerek hüküm kurmaktadır.

\section{A. Adil Yargılanma Hakkı İle İlişsisi}

Türk hukukunda herkes, hem Avrupa İnsan Hakları Sözleşmesi (AİHS)-md. 6/1 ${ }^{130}$ gereği, hem de 1982 AY-md.36/1 ${ }^{131}$ gereği adil yarg1lanma hakkına sahiptir. AİHS-md. 6/1'de medeni hak ve yükümlülükler ile suç isnadından bahsedilmiş olması, sadece hukuk ve ceza davalarına ilişkin uyuşmazlıklarda adil yargılanma hakkının ihlal edilip edilmediğinin değerlendirilmesinde dikkate alınacakmış gibi gözükse de Avrupa İnsan Hakları Mahkemesi (AİHM), birçok idari uyuşmazlıkta medeni hak ve yükümlülüğün ihlal edilip edilmediğini değerlendirmiş ${ }^{132}$ ya da bazı idari davalar ve disiplin işlemleri ile ilgili olarak ceza hukuku niteliğ $i$ değerlendirmesi ${ }^{133}$ yapmıştır. Vergi uyuşmazlıkları açısından, AİHM vergi yükümlülüğünü medeni hak olarak değil kamusal yükümlülük olarak kabul etmekle birlikte, vergi cezalarını suç isnadı kapsamında değerlendirmekte ve vergi aslı ile vergi cezalarına karşı birlikte dava açılması durumunda, bu davaları adil yargılanma hakk1 kapsamında değerlendirmektedir ${ }^{134}$. Böylelikle, vergi uyuşmazlıkları da dâhil olmak üzere tüm idari uyuşmazlıklarda bireylerin adil yargılanma haklarının korunması hukuken zorunludur.

İdari yargılama usulünde tanık dinlenmesinin gerekliliği, en çok adil yargılanma hakkının önemli bir kısmını teşkil eden hakkaniyete uygun yar-

130 AİHS-md. 6/1: "Herkes davasının, medeni hak ve yükümlülükleriyle ilgili uyuşmazlıklar ya da cezai alanda kendisine yöneltilen suçlamaların esası konusunda karar verecek olan, yasayla kurulmuş, bağımsız ve tarafsız bir mahkeme tarafindan, kamuya açık olarak ve makul bir süre içinde görülmesini isteme hakkına sahiptir..."

1311982 AY-md. 36/1: “...Herkes, meşrû vasıta ve yollardan faydalanmak suretiyle yargı mercileri önünde davacı veya davalı olarak iddia ve savunma ile adil yargılanma hakkina sahiptir."

132 Uzun, s. 222; AİHM'in idari dava örneklerinde medeni hak ve yükümlülük değerlendirmesi yapmış olduğu dair karar örnekleri için bkz., Zrvandyan, s. 17-23.

133 Bu yöndeki karar örnekleri için bkz. Zrvandyan, s. 23-27.

134 Uzun, s. 222, 223, 224. 
g1lanma hakk1 ${ }^{135}$ ve özellikle hakkaniyete uygun yargılanma hakkının gereklerinden ${ }^{136}$ olan silahların eşitliği ilkesi ile ilişkilendirilebilir. Usuli eşitlik anlamındaki silahların eşitliği ilkesi, uyuşmazlığın taraflarının yargılamanın her aşamasında hak ve yükümlülükler açısından eşit olması ve böylece dengenin yargılamanın sonuna kadar korunması gerekliliğini içermektedir ${ }^{137}$. Silahların eşitliği ilkesi, ceza yargılamasında, özellikle tanık delili ile ilgili olarak, özel bir öneme sahip olmakla birlikte, ceza ve hukuk yargılamalarında geçerli bir ilke olarak kabul edilmekte ${ }^{138}$ ve bu ilkenin idari yargılama usulünü de kapsamına almakta olduğu belirtilmektedir ${ }^{139}$. Bununla birlikte, silahların eşitliği kapsamında bulunan tanık dinlenmesinde hak eşitliği ise AİHM içtihatlarında genellikle ceza ve hukuk mahkemesi kararları açısından ele alınmıştır ${ }^{140}$. Yine, delillerin değerlendirilmesi ve delillerinin dava ile ilgisini belirleme yetkisinin "esas olarak milli mahkemelerde" olduğu, AİHM içtihatlarında kabul edilen diğer bir husustur ${ }^{141}$. Doktrinde, AİHM' in hakkaniyete uygun yargilamanın mutlaka belirli delillerle yargilama yapılmas1 gerekmediğine ve devletlerin bu hususta serbest olduğuna ilişkin içtihadından hareketle, uyuşmazlık konusu maddi olay başka delillerle de ispatlanabildiği takdirde, salt tanık dinlenmeden yargılama yapılmış olmasının adil yargılama hakkını ihlal etmeyeceği; salt tanıkla ispatın mümkün olduğu olaylarda ise adil yargılama hakkının ihlal edilmiş sayılabileceği belirtilmektedir ${ }^{142}$.

Bununla birlikte, doktrinde idari yargılama usulünde tanıklık kurumuna yer verilmemesinin, "maddi olayın açıklı̆̆a kavuşması ve adaletin gerçekleşmesine izin" vermediği ve bu durumun, "Sözleşmenin 6. Maddesi açısından ihlal kararlart verilmesine aday"143 olduğu; zira, idare hukuku alanında ortaya çıkan uyuşmazlıkların büyük bir kısmının AİHS-md. 6'nın kapsamına

135 İnceoğlu, Sibel: İnsan Hakları Avrupa Mahkemesi Kararlarında Adil Yargılanma Hakkı, Tıpk1 4. Baskı, Beta Basım Yayım Dağıtım A.Ş., İstanbul 2013, s. 217.

136 İnceoğlu, s. 220.

137 İnceoğlu, s. 220.

138 Clayton, Richard/Tomlinson, Hugh: Fair Trial Rights, 2. Bask1, Oxford University Press, 2010, s. 158, 159.

139 İnceoğlu, s. 220; Dinç, Güney: Adil Yargılanma Hakkı, İzmir Barosu Yayınları, İzmir, 2006, s. 168.

$140 \mathrm{Bu}$ hususta ayrıntılı bilgi için bkz. İnceoğlu, s. 223-228.

141 İnceoğlu, s. 316.

142 Yasin, s. 59-60.

143 İnceoğlu, s. 52. 
girdiği ve bu uyuşmazlıkların çözümü sırasında yine AİHS-md.6'nın sağlamış olduğu güvencelerin sağlanması gerektiğ $1^{144}$, belirtilmektedir.

AİHM kararlarında tanık dinletme hakkı, adil yargılama hakkının gerekleri arasında sayılmakta ve mahkemece dava konusu uyuşmazlıkla ilgili olarak gerekli olduğu halde tanık dinlemenin reddedilmesi durumunda adil yargılanma hakkının ihlal edilmiş olarak kabul edilebileceği belirtilmektedir $^{145}$. Aslında, AİHS-md. $6 / 3^{146}$, sadece sanığa ilişkin güvenceleri kapsamakta ve bu hüküm sadece ceza davalarına ilişkin bir hüküm olarak gözükmektedir. Bununla birlikte, AİHM 1993 yılında vermiş olduğu karar1 ${ }^{147}$ ile, silahların eşitliği ilkesi çerçevesinde değerlendirme yaparak, hukuk davalarında da tanık dinlenmesi gerekliliğini hüküm altına almıştır ${ }^{148}$. Doktrinde, AİHM'in 1983 yılında iki doktor hakkında verilmiş olan disiplin cezasına ilişkin başvuruda ${ }^{149}$ olduğu gibi, idari dava türlerinde de tanığa ilişkin uyuşmazlıkları değerlendirdiği belirtilmiştir ${ }^{150}$. Özellikle, dosyada bulunan tanık ifadelerinin karara dayanak teşkil ettiği hallerde, davacı tarafından tanık dinletme talebinin reddedilmesinin silahların eşitliği ilkesine aykırı olacağı belirtilmektedir ${ }^{151}$. İdari rejimi benimsemiş diğer ülkelere bakıldığında, günümüzde bu ülkelerde idari yargılama usulünde duruşmada ya da keşif sırasında mahkemece tanık dinlenmekte olduğu görülmektedir. Örneğin, eskiden yazılı yargılama usulüne sıkı sıkıya bağlı olan Fransa'da bu tutumdan vazgeçilerek sözlülük ilkesi daha önemli bir hale gelmeye başlamış ${ }^{152}$ ve idari davalarda tanık deliline yer verilmeye başlanmıştır ${ }^{153}$. Fransa'da her ne kadar yazıl11lk ilkesi geçerli olmaya devam etse de sözlülük ilkesinin önemi gittikçe yaygınlaşmakta olup, duruşmada tarafların tanıklarını dinletme hakkı bulunmakta ve tanıklar yemin edip dinlendikten sonra beyanları tuta-

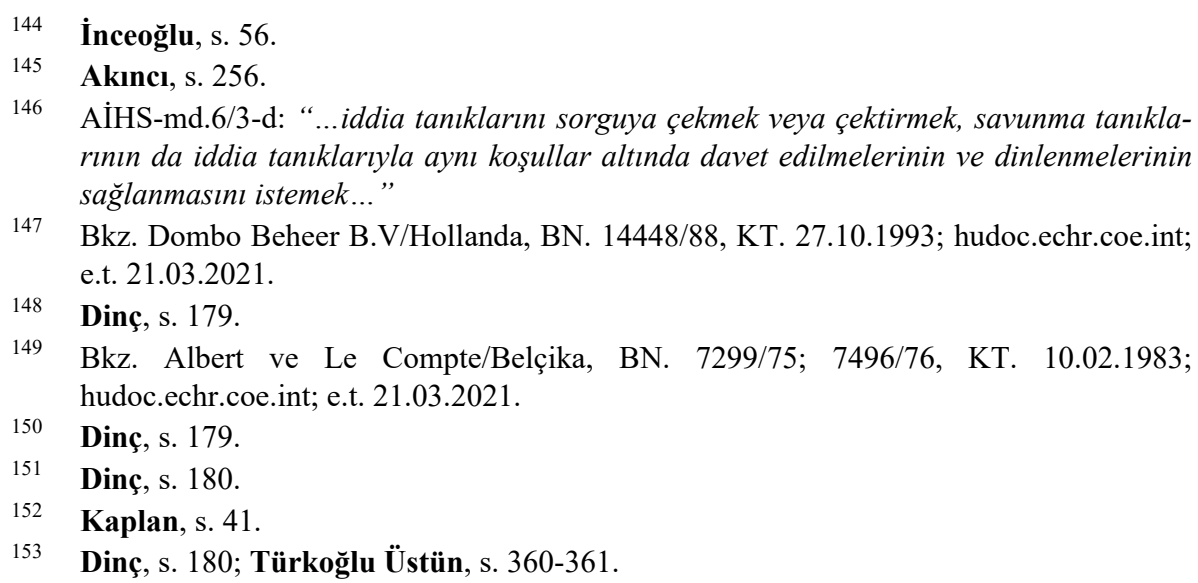


nağa geçirilerek dava dosyasına dâhil edilmektedir ${ }^{154}$. Fransa'da, normal yargılama sürecinde sözlülük ilkesine tamamlayıcı olarak başvurulduğu, yabancıların sınır dışı edilmelerine ilişkin davalarda sözlülük ilkesinin öneminin daha da arttığı ve seri yargılama usulüne tabi davalarda ise yazıl111k ilkesine göre daha önemli bir hale gelmiş olduğu belirtilmiştir ${ }^{155}$. Almanya'da da, idari yargılama usulünde temel olarak sözlülük ilkesi benimsenmiş olup, yargılama sırasında tanık dinlenmesi mümkündür ${ }^{156}$.

Türkiye'de ise, yazllılık ilkesi ve pozitif hukukta tanık dinlenmesi hususunda bir hüküm bulunmaması gerekçe gösterilerek tanık dinlenmemesi ispat hakkını sınırlandırmaktadır ${ }^{157}$. Özellikle idari ceza niteliği taşıyan disiplin cezası, idari yaptırım ya da vergi cezası gibi idari işlemlere ilişkin uyuşmazlıklarda, bu işlemlerin yapılmasına dayanak teşkil eden tanıkların yargılama sırasında da dinlenmesi bir gereklilik olduğundan, bu idari işlemlerin idari yarg1 yerlerince yargılamas1 yapılırken AİHS-md. 6'daki esasların sağlanması gerektiği belirtilmektedir ${ }^{158}$. Aslında, idari yargılama aşamasında tekrar dinlenmese dahi, idari usul aşamasında ya da adli yargı yerleri tarafindan dinlenmiş ve idari yargı yerleri tarafindan verilecek olan karara dolaylı olarak etki eden tanık ifadelerinin, davanın taraflarınca dava ve cevap dilekçesi ile ikinci dilekçeler yolu ile ya da duruşma yapılması durumunda sözlü olarak tartışılması da mümkündür. Ancak, örneğin, dosyada bulunan yazılı tanık ifadeleri arasında çelişki ortaya çıkan durumlarda, idari yargı hâkiminin resen söz konusu tanığı ya da tanıkları dinlemesi, adil yargılanma hakkına ek olarak hukuk devleti ilkesi ve usul ekonomisi ilkesi ${ }^{159}$ ile daha uyumlu bir yaklaşım olacaktır. AİHM'e göre sözlü duruşmanın ve söz konusu duruşmada tanıkların dinlenmesinin adil yargılanma hakkı ile oldukça yakın bir ilişkisi bulunmaktadır. AİHM, adil yargılanma hakkının bir parçası olan aleni duruşma hakkının sözlü duruşmayı da içerdiğini kabul etmekte olup, bu kabulün sebebinin ancak sözlü duruşmanın, davanın taraflarının,

154 Türkoğlu Üstün, s. 364; Fransa'da taraflara tanık dinletme imkânı kanunen tanınmıştır. Bu hususta bkz. Code De Justice Administrative (Cja) -Article R623-3.

155 Kaplan, s. 41-42.

156 Türkoğlu Üstün, s. 361; Almanya'da da, idari yargılama aşamasında kanunen tanık dinlenmesi kabul edilmiş olup, bu yönde ayrıntılı düzenlemelere yer verilmiştir. $\mathrm{Bu}$ hususta bkz. Verwaltungsgerichtsordnung (Vwgo)- Abschnitt-87, 93a, 95, 96, 97, 102a, 180.

157 Türkoğlu Üstün, s. 359.

158 Türkoğlu Üstün, s. 360.

159 Bu hususta usul ekonomisi ilkesi açısından değerlendirme için bkz. Çınarlı/Azak, s. 532. 
tanıkların ve bilirkişilerin dinlenmesini sağlayacağı ve sadece evrak üzerinden yapılan incelemenin duruşmanın aleniliğini zedeleyeceği yönündeki düşünce olduğu belirtilmektedir ${ }^{160}$. AİHM, bu doğrultuda salt teknik nitelik taşımayan ve adil bir karar verilebilmesi için sözlü duruşma yapılmasının ve tanıkların dinlenmesinin önemli olduğuna kanaat getirdiği idari yargı uyuşmazlıklarında adil yargılanma hakkının ihlal edildiğine karar vermişken ${ }^{161}$; idari yargılama aşamasında silahların eşitliği şartları sağlanarak, davacıya yazılı belgeleri sunma ve karşı tarafın sunduğu belgelere de cevap verme hakkı tanındığ 1 ve söz konusu belgelere dayanarak adil bir karar verilebileceğine kanaat getirdiği durumlarda, salt duruşma ve tanık dinletme talebinin kabul edilmemiş olmasını, adil yargılanma hakkının ihlali olarak kabul etmemiştir ${ }^{162}$.

Doktrinde ayrica, 5326 say1l Kanun $^{163}$-md. $28 / 5^{164}$ te yer alan ve CMK'nin tanıklığa ilişkin hükümlerinin, bu kanun kapsamındaki idari yaptırımlardan doğan uyuşmazlıklarda da uygulanacağını belirten hükmün, idari yargılama usulünde de tanık dinlenmesi imkânını sağlamasının hukuk devleti ilkesinin ve adil yargılanma hakkının gereği olduğu belirtilmiştir. Zira, söz konusu kanun, 3. maddesinin başlığında açıkça ifade edildiği üzere, idari yaptırımlar açısından genel nitelikte bir kanundur ve kanunen adli yargının görev alanına alınmış olan idari yaptırımlara karşı açılacak davalarda tanık deliline başvurabilme imkânının idari yaptırımlara karşı idari yargıda açılacak olan davalar açısından da kabul edilmesi gerekmekte olup, idari para cezaları ve vergi cezalarına karşı idari yargıda açılan davalarda tanık dinlenmemesi AİHS-md. 6/1'e aykırı olacaktır ${ }^{165} 166$.

$\mathrm{Bu}$ görüş adil yargılanma hakkı açısından oldukça önemli bir konunun altını çizmiş olmakla birlikte, bu durumun aslında 5326 sayılı Kanun'un

$160 \quad$ Zrvandyan, s. 77.

161 Zrvandyan, s. 86.

162 Zrvandyan, s. 88.

163 Kabahatler Kanunu, RGT. 31.03.2005, RGS. 25772 (Mükerrer).

1645326 say1lı Kanun-md. 28/5: “Ceza Muhakemesi Kanununun tanıklı̆ga, bilirkişi incelemesine ve keşfe ilişkin hükümleri, bu başvuru ile ilgili olarak da uygulanır."

165 Ardıçoğlu, Artuk: "İdari Yargıda Tanık", Yaklaşım, Sayı 215, 2010; www.adaletbiz.com/idari-yargida-tanik-makale, 65.html; e.t. 10.03.2021.; benzer yönde görüş için bkz. Yılmaz (Sözlülük), s. 310-311.

166 Sulh Ceza Mahkemesi'nde açılmış olan idari para cezasına ilişkin uyuşmazlıkta duruşma yapılmadan karar verilmiş olduğu için AİHS-md. 6/1'in ihlal edilmiş olduğuna dair karar örneği için bkz. Hüseyin Turan/Türkiye BN. 11529/02 K.T. 4.03.2008; www.hukukturk.com; e.t.21.03.2021. 
yürürlüğe girmesiyle birlikte değil, daha önce de, başka bir ifadeyle idari bir işlem ya da sözleşme olmasına rağmen kanunen adli yargının görev alanına sokulmuş olan tüm uyuşmazlıklar açısından geçerli olduğu söylenebilir. Zira, bu durumda da kanunen adli yargıda görülecek olan uyuşmazlıklarda taraflar HMK hükümleri doğrultusunda yargılama sırasında tanık dinletebilmekteyken, idari yargıda görülecek olan davalarda tanık dinletememektedir.

Tanık dinletme hakkı ile ilgili olarak, Anayasa Mahkemesi'nin bireysel başvurular sonucu verdiği kararlar da oldukça önemlidir. Öncelikle, Anayasa Mahkemesi, idari yargı kararları sonucu yapılan bireysel başvurularda, tanık dinletme hakkının adil yargılanma hakkı ile ilişkisini açıkça ortaya koymak$\operatorname{tad}^{167}{ }^{167}$. Bunun dışında, idari yargılama aşamasında tanık dinletme taleplerinin reddedilmiş olduğu bazı uyuşmazlık örneklerinde Anayasa Mahkemesi, idari yargıda tanık dinlenemeyeceği gibi bir gerekçeye kararlarında yer vermemektedir. Örneğin; idari yargılama aşamasında yeniden keşif yapılarak keşif sırasında tanık dinletme talebinin mahkemece "idari yargılamada keşif sırasında ya da yargılamanın diğer aşamalarında tanık dinlenemeyeceği”" belirtilerek reddedilmesi üzerine yapılan bireysel başvuru sonucunda Anayasa Mahkemesi adil yargılanma hakkının ihlal edilmediğine karar vermiş, bununla birlikte kararındaki gerekçesi ilk derece mahkemesinin belirtmiş olduğu gibi idari yargıda tanık dinlenemeyeceği yönündeki kabul olmamıştır. Aksine, Anayasa Mahkemesi'nin kararını, açıkça olmasa da, idari yarg1lama hukukunda tanık dinlenmesinin bir gereklilik olduğu ve davanın niteliği gereği tanık delilinin tek başına belirleyici olduğu durumlarda tanık dinletme talebinin kabul edilmemesinin adil yargılanma hakkının ihlali anlamına geleceği şeklinde yorumlamak mümkündür ${ }^{168}$. Bir başka başvuru sonucunda Anayasa Mahkemesi, başvuruya konu olayda her ne kadar "idari yargıdaki yerleşik uygulamada tanık dinleme yoluna gidilmediği anlaşılmıştır" şeklinde bir ifade kullanmış olsa da başvuran idari yargılama sırasında tanık dinlenmesi talebinde bulunmadığı için, adil yargılanma hakkının ihlal edilmediği sonucuna ulaşmıştır. Bu kararda Anayasa Mahkemesi, aynı zamanda, mahkemelerin “... maddi gerçeği açı̆̆a çıkarma amacı gütmeyen tanık beyanı, keşif icrası ve bilirkişi incelemesi gibi delilleri toplamama veya incelememe konusunda takdir yetkisine sahip olduğu" nu belirterek ${ }^{169}$, idari yargılama usulünde tanık dinlenmesinin mahkemenin takdirinde olduğu gibi

167 Örnek için bkz. AYM, BN. 2013/9025, KT. 06.01.2016; AYM, BN. 2013/1989, KT. 10.03.2016; www.hukukturk.com; e.t.25.03.2021.

168 AYM, BN. 2013/6615, KT.20.04.2016; www.hukukturk.com; e.t.25.03.2021.

169 AYM, BN. 2013/2624, KT.31.03.2016; www.hukukturk.com; e.t.25.03.2021. 
bir izlenim uyandırmıştır. Benzer bir başka başvuruda, başvuran idari yargılama aşamasında keşif ve tanık dinletme taleplerinin reddedildiğini belirtmiş, Anayasa Mahkemesi ise tanık dinletme talebinin reddini gerekçe olarak kullanmamakla birlikte, keşif talebinin reddedilmiş olmasını adil yargılanma hakkının ihlali olarak kabul etmiştir ${ }^{170}$.

Görüldüğü gibi, Anayasa Mahkemesi idari yargılama aşamasından kaynaklanan bireysel başvurularda tanık dinletme hakkının adil yargılanma hakkı açısından önemini vurgulamakta, idari yargılama aşamasında tanık dinlenmeyeceğine ilişkin bir belirleme yapmamakta, bununla birlikte somut olayın çözümünde tanık dinletme talebinin reddedilmiş olmasını, adil yarg1lanma hakkının ihlali açısından gerekçe olarak kullanmaktan kaçınmaktadır. Bununla birlikte, Anayasa Mahkemesi'nin idari yargılama aşamasından doğan başvurular sonucu verdiği kararlarda, tanık delilinin adil yargılanma hakkı ve özellikle hakkaniyete uygun yargılanma hakkı ve silahların eşitliği ilkesi ile ilişkisine yer vermesi oldukça önemlidir.

\section{B. Vicdani Kanaat İlkesi İle İlişkisi}

Günümüzde yargılamanın amacının "adaletli karar vermek olduğu” ve adaletli bir kararın ise, dava konusu uyuşmazlığı davanın her iki tarafını da tatmin edecek şekilde ortadan kaldıran hatta toplumsal barışı sağlayan karar olduğu kabul edilmektedir ${ }^{171}$. İdari yargilama usulünde adil karar vermek, bireysel yarar yanında kamu yararını da oldukça yakından ilgilendirmekte olduğundan, kararı verecek hâkimin dava konusu olayla ilgili olarak her türlü bilgiye ulaşması daha önemli hale gelmektedir ve aslında idari yarg1lama usulünde resen araştırma ilkesinin benimsenmiş olmasının temel sebebi budur $^{172}$.

Adil karar verebilmenin en önemli basamaklarından birini, kuşkusuz vicdani kanaat ilkesi oluşturmakta olup, "yargılamanın temel taşı "173 olarak nitelenen bu ilke, Türk hukukunda 1982 AY-md. 138/1 ${ }^{174}$ hükmü ile güvence altına alınmıştır. Yargılama sırasında hâkimin vicdani kanaatinin

170 AYM, BN. 2013/6133, KT.13.04.2016; www.hukukturk.com; e.t.25.03.2021.

171 Yılmaz (Sözlülük), s. 273; Yılmaz, Ejder: "Usul Ekonomisi”, Ankara Üniversitesi Hukuk Fakültesi Dergisi, Cilt 57, Say1 1, Y11 2008, s. 248.

172 Türkoğlu Üstün, s. 344.

173 Işıklar, s. 50; Yeter, Olga Nihal: Türk Vergi Yargılaması Hukukunda Duruşma, Yayımlanmamış Yüksek Lisans Tezi, İstanbul Üniversitesi Sosyal Bilimler Enstitüsü, İstanbul, 2019, s. 23.

1741982 AY-md. 138/1: "Hâkimler, görevlerinde bağımsızdırlar; anayasaya, kanuna ve hukuka uygun olarak vicdanî kanaatlerine göre hüküm verirler." 
oluştuğu yerin duruşma olduğu ve her ne kadar idari yargılama usulünde duruşmaya sınırlı olarak yer verilse de idari yargılama usulünde duruşmanın vicdani kanaatin oluşmasının yolu olduğu belirtilmektedir ${ }^{175}$.

Duruşmanın vicdani kanaat ilkesi ile ilişkisi bu kadar yakınken, idari yargılama usulünde duruşma sırasında tanık dinlenmemesinin ispat hakkı ve hâkimin vicdani kanaatinin oluşması açılarından eksiklik olduğ ${ }^{176}$ kuşkusuzdur. Ayrıca, davanın taraflarınca sunulan delillerin yeterli olmadığı ya da bu delillerin birbirine eşit olduğu ve hâkimin resen araştırma yapmasına rağmen uyuşmazlığ 1 çözmeye yetecek delile ulaşamadığ 1 durumlarda, hâkimin tam olarak vicdani kanaatinin oluşabilmesi için tanık dinlenmesine zorunlu olarak ihtiyaç duyulacaktır ${ }^{177}$. Bu durumlarda tanık dinlenerek bir çözüme ulaşılması, verilecek kararda hâkimin vicdani kanaatinin oluşmasını daha kolay hale getirecektir ${ }^{178}$. Kaldı ki, idari yargıda görülmekte olan mobbing davaları örneğinde olduğu gibi, bazı uyuşmazlıklarda davacının tanık delilinden başka bir delili bulunmamaktadır ${ }^{179}$. Bu durumun davalı idare açısından da geçerli olduğu kuşkusuzdur, aleyhine mobbing davası açılmış olan idarenin de bu iddianın aksini ispatlamak hususunda tanık delilinden başka delili bulunmayabilir.

$\mathrm{Bu}$ sebeplerle, doktrinde idari yargılama usulünde tanık delilinin çok önemli bir ihtiyaç olduğ ${ }^{180}$, idari hâkimin bazı uyuşmazlıklarda istediği usulü benimseyebilmesi gerektiği ve delilleri toplayıp değerlendirmek aşamasında, idari hâkime bazı serbest alanlar tanınması gerektiği belirtilmiş$\operatorname{tir}^{181}$. Yine doktrinde, her ne kadar mutlak bir benzerlik söz konusu olmasa da idari yargılama usulünde iptal davalarının ceza davalarına benzediği ve bu davalarda ceza yargilama usullerinin daha üstün olduğu, tam yarg1 davalarının ise hukuk davalarına benzediği ve bu davalarda hukuk yargılaması usullerinin üstün olduğu belirtilmiştir ${ }^{182}$. Bu noktada, idari yargılama usulünde, ceza yargılamasında kabul edilmiş olan ve delil serbestliğini ve delillerin değerlendirilmesi serbestliğini içermekte olan "vicdanî delil siste$m i$ ”nin ${ }^{183}$ kanunen ya da içtihatla kabul edilmesi gerektiğini söylemek

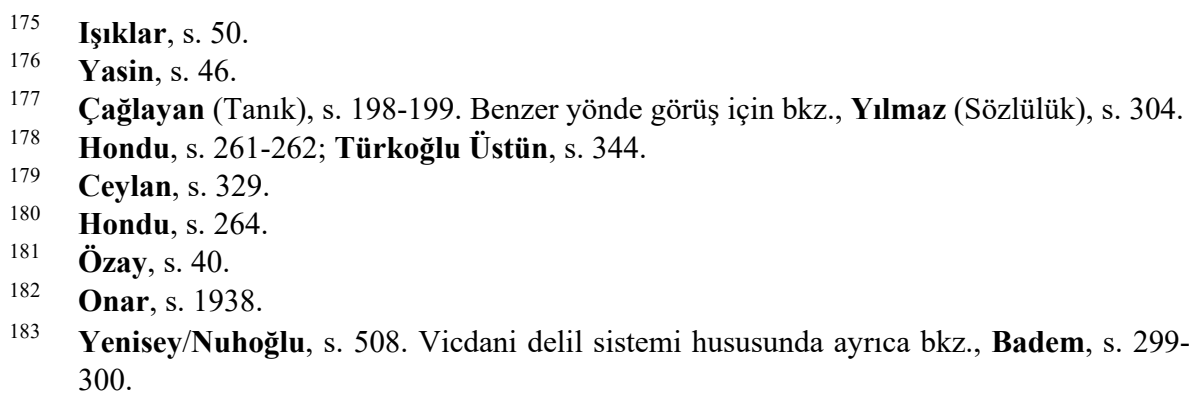


mümkün olup, 1982 AY-md. 138/1'de yer alan vicdani kanaat ilkesinin tüm kamu hukuku alanında geçerli olduğuna ilişkin Anayasa Mahkemesi kararı bu düşünceyi desteklemektedir ${ }^{184}$.

Danıştay ise, vicdani kanaat ilkesine genellikle disiplin cezalarına karşı açılan davalarda vurgu yapmakta ve disiplin cezası verilebilmesi için isnat konusu fiilin "tam bir vicdani kanaat oluşturacak şekilde" ortaya konması gerekliliğini hüküm altına almaktadır ${ }^{185}$. Böylelikle Danıştay, idari ceza alanında idarenin disiplin cezası verirken vicdani kanaatinin tam olarak oluşması gerektiğini kabul etmekte olup, bu içtihadının aslında idari yargıda tanık dinlenmesi hususu açısından da geliştirilmesi gerektiği kuşkusuzdur. Her ne kadar disiplin soruşturmasında vicdani kanaat ilkesinin gerekliliği oldukça önemli olsa da idari yargı yerince verilecek kararlar açısından da bu ilke öncelikle önemli olmaktadır. Zira, disiplin cezası son tahlilde idari bir işlemdir ve bu işleme karşı yargı yolu açıktır. Bu sebeple, idari yargılama aşamasında davanın taraflarının tanık dinletememesi sonucu, idari hâkimin vicdani kanaati tam olarak oluşmadıysa, tanık dinlenmemesi anayasal vicdani kanaat ilkesine aykırılık teşkil edecektir.

Sonuç olarak; gerek adil yargılanma hakkı ve vicdani kanaat ilkesi, gerek İYUK-md. 20/1'de yer alan hükmün yorumu ile idari yargılama aşamasında tanık dinlenmesinin mümkün ve gerekli olduğu hususunda şüphe bulunmamaktadır. Kaldı ki, tanık delili için yasal dayanak olmadığı kabul edildiğinde dahi, idare hukuku gibi idari yargılama usulünün de genç bir hukuk dalı olmasının sonucu olan içtihadi niteliğ $1^{186}$ göz önüne alındığında, idari yarg1 yerlerince tanık deliline başvurma hususunda içtihat değişikliğine gidilebileceği ${ }^{187}$ vurgulanmalıdır. Zira, her ne kadar tanık delilinin IYYUK'ta ayrıca ve açıkça kabul edilerek düzenlenmesi, söz konusu delilin idari yargılama usulünde uygulanabilmesine kesin olarak olanak sağlayacak olsa da doktrinde belirtilmiş olduğu gibi idari yargılama usulündeki düzenlemelerin hukuk yargılama usulündeki düzenlemeler gibi ayrıntılı şekilde düzenlenmemiş olması, aslında "idari yargıda usul hükümlerinin esnek kalma zorun-

184 “...Bu kuralın ceza hukuku dışında kamu hukukunun öbür alanlarda da geçerli olduğu görüşünü Anayasa'nın 138. maddesi de desteklemektedir...”; AYM, E.1993/33, K.1993/0, KT. 21.10.1993; www.hukukturk.com; e.t.18.03.2021.

185 D12D, E.2012/9082, K.2016/408, KT.02.02.2016; D12D, E.2014/29, K.2018/4956, KT.07.11.2018; www.hukukturk.com; e.t.13.03.2021.

186 Yavuzdoğan, s. 13-15. Bu hususta ayrıca bkz. Eroğlu, s. 24. Bu içtihadi nitelik, kanunda açıkça düzenleme olmayan ve HUMK'ye atıf yapılmayan hallerde içtihatlara yer verilmesi, şeklinde açıklanmıştır; Onar, s. 1941, 1942.

187 Kaplan, s. 44; Ceylan, s. 331; Yılmaz (Sözlülük), s. 308. 
luluğu”ndan kaynaklanmaktadır ${ }^{188}$. Doktrinde, “yasa koyucunun hareketsizliği"nin, "içtihadi çözüm”e engel teşkil etmediğ $i^{189}$ ve içtihat mahkemesi olarak Danıştay'ın hukukun genel ilkelerinden ve hukuk yargılamasındaki kurallardan yararlanarak bir çözüme ulaşmasının mümkün olduğu ${ }^{190}$, hakl1lıkla belirtilmektedir. Buna ek olarak, idari yargılama sırasında ihtiyaç duyulması halinde CMK'nin tanık deliline ilişkin hükümlerinden de yararlanılabileceğinin altı çizilmelidir.

Son olarak, Adalet Bakanlığı tarafından 2020'de yayımlanmış olan Yarg1 Reformu Stratejisi Eylem Planı'nda 2021 yılında mevzuat değişikliği ile bazı uyuşmazlıklarda tanık dinlenebilmesinin sağlanacağı belirtilmiştir ${ }^{191}$. 20 Aralık 2018-20 Aralık 2021 tarihleri arasını kapsayan "İdari Yargının Etkinliğinin Artırılması ve Danıştayın Kurumsal Kapasitesinin Güçlendirilmesi" projesi ile ilgili olarak da bu proje faaliyetleri arasında beklenen sonuçlar arasında ilk sırada, "Mevcut idari yargı sisteminin derinlemesine incelenmesi ve uygulanan reformların etkilerinin değerlendirilmesi" ve proje aracılığıyla ulaşılması öngörülen sonuçlar arasında, "idari yargının etkililiğinin iyileştirilmesi yönünde yaklaşım ve politikaların (kanıt esaslı) belirlenerek, bunların uygulanmasının desteklenmesi”, gösterilmiştir ${ }^{192}$. Gerek söz konusu projenin amaçları, gerek yargı reformu stratejisi birlikte değerlendirildiğinde, idari yargılama usulünde tanık dinlenmesine olanak sağlayacak düzenlemelerin yapılması beklenen bir gelişme olmaktadır. Bununla birlikte, söz konusu mevzuat değişikliğinin, bu çalışmada açıklanmaya çalışılan ve idari yargılama usulünde adil yargılanma hakkının ve vicdani kanaat ilkesinin tam olarak hayat bulmasına yönelik içeriğe sahip olması ve tüm idari uyuşmazlıklarda tanık dinlenmesi imkânını sağlaması umulmaktadir.

188 Eroğlu, s. 24.

189 Kaplan, s. 41

190 Eroğlu, s. 32; Gözübüyük/Tan, s. 728. Bu hususta ayrıca bkz. Çağlayan (İdarî Yargilama), s. 391-392.

191 Adalet Bakanlı̆ğ: Yarg1 Reformu Stratejisi Eylem Planı, 2020, s. 108; https:// yargireformu.adalet.gov.tr/Resimler/eylemplani.pdf; e.t.02.04.2020.

192 Bu hususta bkz.; Türkiye Avrupa Konseyi Program Ofisi Ankara: "Proje Hakkında"; https:// www. coe. int/tr/web/ankara/improving-the-effectiveness-of-the administrativejudiciary-and-strengthening-the-institutional-capacity-of-council-of-state; e.t. 02.04 .2020 . 


\section{SONUÇ}

Danıştay, idari yargılama aşamasında tanık dinlenmesini kabul etmemekle birlikte, idari usul sürecinde ve adli yarg1 yerlerince dinlenmiş olan tanıkların ifadelerini bazı kararlarında delil olarak kullanmaktadır.

Danıştay'ın idari yargılama usulünde tanık dinlenemeyeceğine ilişkin içtihadı vergi uyuşmazlıklarından temellenmiş ve az sayıdaki başka tür idari uyuşmazlıkta da söz konusu içtihadında yer alan gerekçelere başvurulmuştur. Bununla birlikte, bu yöndeki kararları oldukça az sayıdadır. Söz konusu gerekçeler, IYYUK-md.1/2'de yazılı yargılama usulünün benimsenmiş olması ile İYUK-md. 31'de tanık delili ile ilgili olarak HMK'ye atıf yapılmamış olmasıdır. Bununla birlikte, yazılı yargılama usulünün benimsenmiş olması tek başına tanık dinlenmesine engel olmadığg gibi; Danıştay'ın tanık delilinden başka usul kuralları ile ilgili olarak HMK'ye atıf yapılmadığı halde HMK hükümlerini uyguladığı çok sayıda kararı bulunmaktadır. Danıştay'ın yargılama sırasında başvurulacak usul kuralları ile ilgili olarak CMK hükümlerini uygulamış olduğu bir kararına bu çalışma kapsamında ulaşmak mümkün olmamıştır. Ancak, resen araştırma ilkesinin geçerli olduğu ceza yargılamasının tanığa ilişkin hükümlerinin de özellikle davanın taraflarınca tanık dinletilmesi talep edilmediği halde, idari hâkimin uyuşmazlığın çözümü açısından ihtiyaç duyması halinde resen tanık dinlenmesine karar vermesi açısından uygulanabileceğini söylemek mümkündür. Bu sebeplerle, Danıştay'ın bu husustaki içtihadının yeniden kurgulanması gerekmektedir.

Danıştay idari usul sürecinde tanık dinlemenin önemini ise, çok say1daki kararında vurgulamakta ve özellikle disiplin soruşturması sırasında dinlenmiş olan tanıkların ifadelerini çok sayıdaki kararında gerekçe olarak kullanmaktadır. Bu sebeple, her ne kadar yargılama aşamasında sözlü olarak tanık dinlenmese de yazılı bir niteliğe kavuşmuş olan tanık ifadeleri idari yargılama aşamasında önemli bir delil olmaktadır.

İdari yargılama aşamasında tanık dinlenmemesi, adil yargılanma hakkı ve vicdani kanaat ilkesi açısından bazı olumsuzlukları beraberinde getirmektedir. Bu husus Avrupa İnsan Hakları Mahkemesi kararlarında ve bireysel başvuru sonucu Anayasa Mahkemesi'nin vermiş olduğu kararlarda vurgulanmaktadır. İdari rejimi benimsemiş diğer ülke örneklerine bakıldığında, idari yargılama aşamasında tanık dinlenmekte olduğu görülmektedir. Böylelikle, idare hukuku doktrininde uzun zamandır önemi vurgulanmış olan sözlü tanık ifadesinin, idari yargılama usulünde hâlen kanunen ya da içtihatla kabul edilmemiş olması önemli bir eksikliktir. 
Bunun dışında, özellikle disiplin soruşturmaları sırasında alınan tanık ifadeleri ile ilgili olarak Avrupa İnsan Hakları Mahkemesi'nin adil yarg1lanma hakkı güvencelerinin sağlanmasına ilişkin içtihadı ve Danıştay'ın disiplin soruşturmalarında, soruşturmacıda tam bir vicdani kanaat oluşması gerektiğine ilişkin içtihadı değerlendirildiğinde; idari yargılama sürecine dolaylı olarak etki eden tanık delili açısından da adil yargılanma hakkının ve vicdani kanaat ilkesinin önemi ortaya çıkmaktadır. Bu durumda, idari usul sürecinde aranan adil yargılanma hakkı ve vicdani kanaat koşullarının, yargılama aşamasında öncelikle önemli olduğu söylenebilir.

Böylelikle, idari yargılama usulünde tanık dinlenebilmesine imkân tanıyan mevzuat değişikliğinin yapılması, idari yargının geliştirilmesine yönelik çalışmaların yapıldığı günümüz açısından öncelikli beklenti olsa da mevzuat değişikliği olmaması durumunda dahi, Danıştay'ın resen araştırma ilkesi, adil yargılanma hakkı ve vicdani kanaat ilkesi doğrultusunda tanık dinlenmesine yönelik içtihat değişikliğine gitmesi, hakkaniyete ve çağın koşullarına uygun bir yaklaşım olacaktır. 


\section{KAYNAKLAR}

Adalet Bakanlığı: Yarg1 Reformu Stratejisi Eylem Plan1, 2020, s. 108; https://yargireformu.adalet.gov.tr/Resimler/eylemplani.pdf; e.t.01.04.2020.

Akıncı, Müslüm: İdari Yargıda Adil Yargılanma Hakkı, Turhan Kitabevi, Ankara, 2008.

Akyılmaz, Bahtiyar: İdari Usul İlkeleri Işığında İdari İşlemin Yapılış Usulü, Yetkin Yaymevi, Ankara, 2000.

Akyılmaz, Bahtiyar/Sezginer, Murat/Kaya, Cemil: Türk İdari Yargılama Hukuku, 2. Bask1, Savaş Yayınevi, Ankara, 2019.

Ardıçoğlu, Artuk: "İdari Yargıda Tanık", Yaklaşım, Sayı 215, 2010; www.adaletbiz.com/idari-yargida-tanik-makale,65.html; e.t. 10.03.2021.

Azrak, Ali Ülkü: Umumi İdari Usulün- Teorik Esasları ve Çeşitli Hukuk Sistemlerinde Gelişimi, Doktora Tezi, İstanbul, 1964.

Badem, Semiyet: "Ceza Muhakemesi Hukukunda Tanık", Türkiye Adalet Akademisi Dergisi, Say1 45, Y11 12, 2021, ss. 289-326.

Ceylan, Mahmut: "İdari Yargıda Delil Serbestisi ve Sinırları", Karadeniz Teknik Üniversitesi Sosyal Bilimler Enstitüsü Sosyal Bilimler Dergisi, Y11 8, Say1 16, Aral1k 2018, ss. 325-341.

Clayton, Richard/Tomlinson, Hugh: Fair Trial Rights, 2. Bask1, Oxford University Press, 2010.

Çağlayan, Ramazan: "İdari Yargılama Usulünde Tanık Delilini Yeri”, Selçuk Üniversitesi Hukuk Fakültesi Dergisi, Cilt 11, Say1 3-4, Y11 2003, ss.195-206. (Tanık)

Çağlayan, Ramazan: İdarî Yargılama Hukuku, Güncellenmiş 9. Bask1, Seçkin Yayıncılık, Ankara, 2017. (İdarî Yargılama)

Çebi Buğdaycı, Melike Özge: "İdari Yargılama Usulünde Keşif Delili”, Selçuk Üniversitesi Hukuk Fakültesi Dergisi, Cilt 29, Sayı 1, 2021, ss. $1-45$.

Çınarlı, Serkan/Azak, Kerim: "Danıştay Kararları Işığında İdari Yargıda Disiplin Cezalarının İptali Davalarında Tanık Delili Sorunu”, Selçuk Üniversitesi Hukuk Fakültesi Dergisi, Cilt 29, Say1 1, 2021, ss. 509535.

Dinç, Güney: Adil Yargılanma Hakkı, İzmir Barosu Yayınları, İzmir 2006. 
Eroğlu, Yaşar: "Danıştay Kanunuyla hukuk Usulü Muhakemeleri Kanunu'na Atıf Yapılmayan Hallerde Hukuk Usulü Muhakemeleri Kanunu'nun Danıştayda Uygulanışı", Danıştay Dergisi, Sayı 8, Y11 3, 1973, ss. 24-32.

Gedik, Doğan: "Ceza Muhakemesinde Hakimin Delilleri Değerlendirme Serbestliği (CMK m. 217)", Dokuz Eylül Üniversitesi Hukuk Fakültesi Dergisi, Prof. Dr. Durmuş TEZCAN'a Armağan, Cilt 21, Özel Say1, 2019, ss. 913-963.

Gözübüyük, A. Şeref/Tan, Turgut: İdare Hukuku Cilt II, Güncelleştirilmiş 7. Bask1, Turhan Kitabevi, Ankara, 2014.

Hondu, Selçuk: "İdari Yargılama Usulünde Deliller ve "Şahit"”, Özay İl Han, Günışı̆̆ında Yönetim II Yargısal Korunma, Filiz Kitabevi, İstanbul, 2004, ss. 253-265.

Işııklar, Celal: "İdarî Yargıda Duruşma”, Türkiye Adalet Akademisi Dergisi, Cilt 2, Y11 2, Say1 4, 2011, ss. 45-100.

İnceoğlu, Sibel: İnsan Hakları Avrupa Mahkemesi Kararlarında Adil Yargılanma Hakkı, Tıpkı 4. Baskı, Beta Basım yayım Dağıtım A.Ş., İstanbul, 2013.

Kaplan, Gürsel: "İdari Yargılama Hukukunda Sözlülük Usulü ve Tanık Dinlenebilmesi Hakkında Kısa Bir Değerlendirme", İstanbul Kültür Üniversitesi Hukuk Fakültesi Dergisi, Cilt 13, Sayı 1, Y11 13, ss. 33-46.

Karamercan, Fatih: "Medenî Usûl Hukukunda Tanık ve Tanıklık", Ankara Barosu Dergisi, Say1 3, 2018, ss. 151-191.

Kuru, Baki: Medenî Usul Hukuku, Legal Yayıncılık A.Ş., İstanbul, 2015.

Ocak, Memduh: "İdari Yargıda Duruşmanın Adil Yargılanma Hakkı Açısından İncelenmesi”, Türkiye Barolar Birliği Dergisi, Sayı 145, 2019, ss.349-367.

Onar, Sıddık Sami: İdare Hukukunun Umumî Esasları, Cilt III, 3. Bask1, İsmail Akgün Matbaas1, İstanbul, 1966.

Özay, İl Han: Günışığında Yönetim II Yargısal Korunma, Filiz Kitabevi, İstanbul, 2004.

Sancakdar, Oğuz/Altınok Çalışkan, Elif/Dursun, Gizem/Seyhan, Serkan/Yağcı, Pınar: Disiplin Hukuku, Turhan Kitabevi, Ankara, 2019.

Türkiye Avrupa Konseyi Program Ofisi Ankara: "Proje Hakkında"; https:// www. coe. int/tr/web/ankara/improving-the-effectiveness-of-the 
administrative- judiciary-and-strengthening-the-institutional-capacityof-council-of-state; e.t. 01. 04. 2020.

Türkoğlu Üstün, Kâmile: İdari Yargılama Usulüne Hâkim Olan İlkeler, Seçkin Yayıncılık, Ankara, 2019.

Uzun, Mine: "Bir Adil Yargılanma Hakkı Olarak Tanı̆̆ Sorgulama Ve Tanık Dinletme Hakkının Türk Vergi Yargılamasındaki Yeri", Ankara Üniversitesi Hukuk Fakültesi Dergisi, Cilt 63, Sayı 1, 2014, ss. 219245.

Yasin, Melikşah: İdari Yargılama Usulünde İspat, On İki Levha Yayıncılık, İstanbul, 2015.

Yavuzdoğan, Seçkin: İdari Yargılama Usulü Kanunu'nun 31. Maddesi Çerçevesinde Medeni Yargılama Hukuku-İdari Yargilama Hukuku İlişkisi, Yayımlanmamış Doktora Tezi, İstanbul Üniversitesi Sosyal Bilimler Enstitüsü, İstanbul, 2007.

Yenisey, Feridun/Nuhoğlu, Ayşe: Ceza Muhakemesi Hukuku, Güncellenmiş 8. Baskı, Seçkin Yayıncılık, Ankara, 2020.

Yeter, Olga Nihal: Türk Vergi Yargılaması Hukukunda Duruşma, Yayımlanmamış Yüksek Lisans Tezi, İstanbul Üniversitesi Sosyal Bilimler Enstitüsü, İstanbul, 2019.

Yılmaz, Ejder: "Usul Ekonomisi", Ankara Üniversitesi Hukuk Fakültesi Dergisi, Cilt 57, Say1 1, Y11 2008, ss. 243-274.

Yılmaz, Dilşat: “ "Usul Ekonomisi İlkesi” Çerçevesinde Türk İdari Yargılama Usulünde Sözlülük İlkesine İlişkin Bazı Değerlendirmeler”, Ankara Hacı Bayram Veli Üniversitesi Hukuk Fakültesi Dergisi, Cilt XXIII, Say1 2, Y11 2019, ss. 267-320.(Sözlülük)

Zrvandyan, Arman: İdari Yargıda Avrupa Adil Yargilanma Standartlarına İlişkin Emsal Kararlar, 2021; https://rm.coe.Int/ emsalkararlarkitabioption-2/1680a1cdb6; e.t.01.04.2021. (Kitap, Avrupa Birliği, Türkiye Cumhuriyeti ve Avrupa Konseyi tarafindan ortaklaşa finanse edilmekte ve Avrupa Konseyi tarafindan yürütülmekte olan "İdari Yargının Etkinliğinin Artırılması ve Danıştayın Kurumsal Kapasitesinin Güçlendirilmesi” projesi kapsamında basılmıştır.) 